NBER WORKING PAPER SERIES

SECULAR PATTERNS IN CORPORATE FINANCE

Robert A. Taggart, Jr.

Working Paper No. 810

NATIONAL BUREAU OF ECONOMIC RESEARCH

1050 Massachusetts Avenue

Cambridge MA 02138

December 1981

J. L. Kellogg Graduate School of Management, Northwestern

University. The author is grateful to the National Bureau of Economic Research for financial support and to Michael Burda and Wing Woo for research assistance. The research reported here is part of the NBER's research program in Financial Markets and Monetary Economics and project on the Changing Role of Debt and Equity Finances in the United States, which is being financed by a grant from the American Council of Life Insurance. Any opinions expressed are those of the author and not those of the National Bureau of Economic Research. 
Trends in the financing of the corporate sector have been widely discussed in both business and academic circles. It is frequently argued, for example, that corporations' use of debt financing has increased dramatically in recent years. These discussions have been hampered, however, by the lack of a unified theoretical framework. In this paper, an attempt is made to develop such a framework using existing corporate finance theory and some extensions thereof. This theory is then used to interpret available data on aggregate corporate financing patterns over the course of the twentieth century •

It is found that corporations' use of debt has undeniably increased in the post-World War II period. Nevertheless, the relative corporate debt level was unusually low in the $1940^{\prime} \mathrm{s}$ and current debt levels are not unprecedented when viewed in the context of the entire century. The tax system, in conjunction with inflation, has probably played an important role in the postwar increases in corporate debt, but these factors appear insufficient to explain longer-term trends. It is argued, then, that supplies of competing securities, such as federal government bonds, as well as the secular development of the financial intermediary system, may also be important determinants of long-run corporate financing patterns.

Robert A. Taggart, Jr. J.L. Kellogg Graduate School of Management Northwestern University

Evanston, Illinois 60201

(312) $492-3562$ 


\section{SECULAR PATTERNS IN CORPORATE FINANCE}

For many years patterns in the corporate sector's sources of finance have been observed, discussed and sometimes decried. ${ }^{1}$ Yet there is little consensus on how to interpret these patterns and even some disagreement over what the patterns have been. Some studies argue that corporate debt ratios exhibit a secular upward trend, for example, while others assert that the debt-equity mix has shown remarkable stability. ${ }^{2}$

Apart from differences in measurement techniques, a major contributor to this lack of consensus has been the absence of a theoretical framework. With few exceptions, the trends observed in previous studies have been discussed without reference to any detailed model of the determinants of corporate finance. ${ }^{3}$ This state of affairs may seem odd in view of corporate capital structure's role as one of the central theoretical questions in finance. ${ }^{4}$ However, a number of these empirical studies were completed before theoretical work had progressed very far, and in many cases these studies discussion of corporate financing patterns has been a by-product of some broader concern, such as capital formation, tax policy or the evolution of the financial system as a whole. More important, perhaps, most theoretical work has been aimed at the individual firm and, until very recently, little analysis has been explicitly devoted to the determinants of corporate finance at the aggregate level. ${ }^{5}$

This paper attempts to improve upon the existing literature by the first developing a detailed theory of capital structure for the corporate sector as a whole and then using that theory as a guide in interpreting 
empirical regularities. Existing theory is culled and extended with a specific eye toward isolating those factors that should influence the aggregate corporate financing mix over time.

The paper consists of three sections the first of which develops the theory. The major aim of that theory is to identify the forces affecting aggregate supplies and demands for corporate securities relative to competing securities in the capital market. It is argued that previous theoretical work has tended to rely on extreme assumptions about supply curves, demand curves or both, and that these assumptions may not be appropriate when the aim is to understand secular patterns in corporate finance. The second section presents a variety of measures of corporate financing activities. Observations from a number of previous studies are gathered and updated in order to present the broadest possible perspective on capital structure trends from the beginning of this century to the present. The third section offers some preliminary explanations for these trends based on the theoretical considerations of Section I.

To preview some of the major conclusions, it is found that there has been an undeniable trend toward greater use of debt financing by corporations in the post-World War II period. Nevertheless, the relative level of corporate debt was unusually low around the time of World War II and current debt levels are not unprecedented when viewed in the context of the twentieth century as a whole. The tax system, in conjunction with inflation, has probably played an important role in the postwar increases in corporate debt, but these factors appear insufficient to explain the trends over longer periods of time. In 
particular, it is argued that supplies of competing securities, such as federal government bonds, as well as the secular development of the financial intermediary system, may also be important determinants of long-run corporate financing patterns.

\section{A Theory of the Aggregate Corporate Capital Structure}

A. The Place of the Corporat Bector in the Overall Financial Sustem One contention of the theur: :o be developed in this section is that the corporate sector's financing activities should be viewed in the context of the other sectors of the economy. Accordingly, the paragraphs that follow offer some prefatory remarks on the corporate sector's place in the overall financial system. The aim of this discussion is to develop a general framework for understanding the determinants of the supply and demand for corporate securities. In Section I.B. some existing theoretical contributions are briefly surveyed with an eye toward drawing out their implications for these supply and demand curves, while in Section I.C. an attempt is made to flesh out the theory and provide a more complete picture of how the supply and demand curves are conditioned by the other sectors of the financial system.

Let us begin by considering a stylized three-sector economy consisting of households, nonfinancial corporations and financial institutions. If we consolidated the balance sheets of the three sectors all financial assets would cancel, as 
they have both issuers and holders, and we would be left with just tangible assets on the left-hand side and household net worth on the right. We could thus conclude that the economy's ultimate wealth is its tangible assets while the household sector is the ultimate wealthholder.

Nevertheless, this consolidation masks the role of the financial system in reconciling the characteristics of the tangible assets with households' planned consumption patterns.

That role emerges if we examine the separate balance sheets of the three sectors, as shown in Figure 1 .

Households accumulate assets because of discrepancies between their desired consumption plans and their patterns of labor income. To some extent tangible assets, such as houses and consumer durables, serve this purpose by producing streams of services that households can consume directly and by acting as inflation hedges. In other respects, however, tangible assets may not be the ideal household savings vehicle. Productive equipment, for instance, requires special expertise to maximize the value of its return stream. Tangible assets are rarely traded on organized markets and may not be easily convertible into cash. Moreover, their pattern of returns may not coincide with households' desired consumption patterns. Tangible assets may provide riskier return patterns, for example, than most households desire or may not yield sufficiently high payoffs under contingencies that are important to households, such as death or illness. 
To help reconcile these desires by households with the tangible asset characteristics, then, the economy develops a financial structure, consisting of nonfinancial corporations, securities markets and financial institutions. Corporations specialize in holding and operating tangible assets and issue claims against these assets in the form of debt and equity securities. Households may prefer allocating some portion of their wealth to such securities because they require less management than tangibles, are more easily traded and can be combined in varying proportions to transform and rearrange the tangible assets' return streams. Even the degree of transformation possibilities inherent in corporate securities may not be fully adequate to match households' desired consumption patterns, however, and this creates a role for financial institutions. Banks, insurance companies, pension funds and mutual funds, for example, hold corporate securities and in turn issue their own claims having different liquidity characteristics and different,patterns of return. Furthermore, some of these institutions purchase household debt securities as well, thus affording individuals further transformation opportunities on their own account.

Viewing the financial system from this perspective emphasizes the idea that corporate capital structure in the aggregate is ultimately a matter households' demands for asset characteristics on the one hand and the corporate sector's 
financial transformation technology on the other. On the demand side, households' desires for various asset characteristics will reflect such factors as their attitudes toward risk, their expectations, their stage in the life cycle and personal tax considerations. Moreover, the elasticities of these demands depend on substitutability among assets, which in turn depends on the degree of competition among corporations, financial institutions and households themselves in performing the desired transformations. The more highly developed the financial intermediary system and the broader the range of transformation opportunities possessed by households on their own account, the less likely it is that corporate securities will possess unique characteristics, and the more elastic the demands for these securities will be. On the supply side, the corporate sector's willingness to transform the return streams from its real assets by issuing various combinations of financial securities depends on the costs of doing so, including transaction costs and tax considerations.

A theory of aggregate corporate capital structure, therefore, should explain the interaction of both supply and demand factors and should illuminate the ways in which the corporate sector responds to changing household demands over time, in competition with similar responses from financial institutuions and households themselves. ${ }^{6}$ In Section I.B., it will be argued that previous analyses of corporate capital structure have tended to 
make extreme assumptions about either the supply or demand side of the market or both. Although such assumptions have proved useful in isolating the role of such factors as taxes and agency costs, they may not be appropriate if what one wishes to understand is the unfolding of corporate capital structure over time.

\section{B. Implications of Existing Theory for the Determinants of}

\section{Aggregate Corporate Capital Structure}

Although much of previous theoretical work has examined the financing decisions of individual firms, it nevertheless contains implications for corporate finance in the aggregate. The purpose of this section is to draw out those implications. To provide a uniform framework, we will analyze the aggregate supply and demand curves for corporate debt implied by a number of previous contributions. In the diagrams that follow, the aggregate amount of corporate debt, B, will be measured along the horizontal axis, and since investment will be held fixed, movements along this axis represent substitutions of corporate debt for equity. On the vertical axis will be measured the certainty equivalent yields on corporate debt, $r$, and on corporate equity, $r_{e^{*}}{ }^{7}$

Modigliani and Miller's (MM, 1958) analysis of corporate capital structure is the logical place to begin, both because it remains the most widely-ited paper on the topic, and because 
it represents the furthest extreme in assumptions about the elasticities of supply and demand for corporate debt. As depicted in Figure 2, both elasticities are assumed to be infinite. Supply is perfectly elastic because corporations can costlessly transform their financing mixes from all-equity to any degree of leverage. Thus they are willing to freely substitute one form of financing for the other as long as both have the same certainty-equivalent cost. But demand is likewise perfectly elastic because households can costlessly perform the same transformations on their own account, and thus they will be unwilling to accept any yield differential between the two securities.

This configuration of supply and demand implies that corporate capital structure is indeterminate not only at the individual firm level but also at the level of the corporate sector as a whole, since corporate and household financial transformation are perfectly substitutable. ${ }^{8}$ While this analysis emphasizes the important fact that corporations face competition from other sectors in their financial transformation activities, however, it also doesn't tell us much about factors that would cause the corporate financing mix to change over time. As long as equilibrium in the capital market were continuously maintained, such changes would be largely random events.

Following MM's (1963) correction, which took the effect of corporate taxes into account, a theory that gained 
considerable support took the tradeoff between bankruptcy costs and tax savings from the deductibility of interest to be the primary determinant of corporate capital structure. 9 Under this theory the demand for corporate debt is still perfectly elastic, because investors are willing to freely substitute debt for equity as long as their certainty-equivalent yields are equal. ${ }^{10}$. The supply of debt is no longer perfectly elastic however, Because of the tax-deductibility of interest, corporations would be willing to pay a certainty-equivalent yield on the first dollar of debt equal to $\left(1 / 1-t_{c}\right)$ times the certainty-equivalent yield on equity, where $t_{c}$ is the corporate tax rate. As more debt is issued, the probability of bankruptcy increases, and if bankruptcy imposes costs on firms, the premium rate that they are willing to pay to issue debt decreases. Thus the supply curve for corporate debt is downward sloping, as depicted in Elgure 3. Equilibrium is reached when the corporate sector has issued that amount of debt which drives the certainty-equivalent yields on debt and equity into equality. Furthermore, since bankruptcy costs are firm-specific, the optimal capital structure is determinate at the individual firm level as well as at the aggregate level.

According to this theory, the primary determinants of changing patterns in corporate finance would be changes in corporate tax rates and changing perceptions of bankruptcy costs. As corporate tax rates increase, the supply curve for 
corporate debt shifts upward, and the equilibrium amount of debt increases. An unappealing implication, however, is that if the corporate tax rate goes to zero, the supply'curve for debt will slope downward from the point $\mathrm{r}_{\mathrm{e}}$ on the vertical axis and thus no corporate debt at all should be issued. This is clearly contrary to observed corporate capital structures in the U.S. prior to the imposition of the income tax in 1913. Changes in the impact of bankruptcy costs would also shift the supply curve for debt upward or downward. This might occur if the efficiency with which bankruptcies are resolved increases or decreases over time or even if the perceived risk of bankruptcies changes over, say, the course of the business cycle.

The agency theory of Jensen and Meckling (1976) is diagrammatically similar to the tax savings - bankruptcy costs theory, but some of its implications are different. Again the demand curve for corporate debt is perfectly elastic at the level $\mathrm{r}_{e}$. Likewise the supply curve has its intercept at a point above $\mathrm{r}_{e}$, because, starting from all-equity financing, the firm can reduce total agency costs associated with outside financing by substituting a dollar of debt for a dollar of outside equity. Thus the firm would be willing to pay a higher certainty equivalent yield on debt to reflect this advantage. As more debt is issued, however, its ability to reduce agency costs at the margin declines and eventually turns 
negative, so the supply curve is downward-sloping, as depicted in Figure 4. The difference between this theory and the previous one is that the curves would look like this even in the absence of corporate taxes. ${ }^{11}$ The primary determinants of changing patterns in corporate capital structure would be changes in relative agency costs of debt and equity.

The theory that contains perhaps the most implications for the aggregate corporate capital structure, and indeed the only one that is explicitly aimed at the capital structure of the corporate sector as a whole, is Miller's (1977) "Debt and Taxes" model. Here, the supply curve is horizontal since, apart from tax considerations, corporations can costlessly split their return streams into debt and equity portions. Furthermore, because of the tax-deductibility of interest they are willing to pay a premium. yield $\left(r_{e} / 1-t_{c}\right)$ to issue debt. Unlike the three theories discussed above, however, personal taxes are considered, and the demand curve is upward sloping, starting from $\mathrm{r}_{\mathrm{e}}{ }^{12}$ This is because investors are arrayed in groups subject to successively higher personal tax rates and because tax arbitrage restrictions make it costly for them to mitigate the differing tax consequences of different securities. Thus, since returns on corporate debt are taxed more heavily at the personal level than returns on corporate equity, investors in successively higher tax brackets must 
be enticed with successively higher yields to buy these bonds. As depicted in Figure 5, equilibrium occurs when enough bonds have been issued to drive the corporate bond rate up to $\mathrm{r}_{\mathrm{e}} / 1-\mathrm{t}_{\mathrm{c}}$.

In contrast to the tax savings-bankruptcy cost theory and the agency cost theory, however, corporate capital structure is determinate only at the aggregate level, not at the individual firm level. As in the original M model, corporations and households compete with one another to perform financial transformations, but here they do not all compete on equal terms. Corporations that issue debt reap tax savings at the rate $t_{c}$ per dollar of interest, and thus they have a comparative advantage in borrowing over those investors with personal tax rates lower than $t_{c}$. It will thus pay corporations to keep on borrowing until the marginal shareholder is just indifferent between buying levered shares and borrowing on his own account to buy unlevered shares. This will occur when the marginal shareholder's tax rate is just equal to $t_{c}$. Nevertheless, this comparative advantage applies to the corporate sector as a whole, but not to any individual firm. One corporation's debt is as good as any other's, and thus in equilibrium capital structure is of no consequence at the firm level.

One appealing feature of Miller's model is that the equilibrium condition, which may be written as

$$
1-\frac{r}{r_{0}}\left(1-t_{c}\right)=0
$$


lends itself particulary well to comparative statics exercises on the determinants of the aggregate amount of corporate debt. The equilibrium condition itself can be thought of as an implicit function, $\mathrm{H}\left(\mathrm{B}^{*}, \mathrm{f}\right)=0$, of the optimal amount of corporate debt, $B^{*}$, and a variety of exogenous factors, $f$, such as tax tates, the inflation rate and supplies of competing securities. Implicit differentiation can then be used to determine the effect of changes in these factors on the equilibrium quantity of corporate debt. Because of their usefulness in interpreting the capital structure trends described in Section II, it is worthwhile at this point to work through the details of a few of these exercises.

The effect of a change in the corporate tax rate, $t_{c}$, for example, holding all other factors constant, would be given by

$$
\frac{\partial B^{*}}{\partial t_{c}}=\frac{\partial H / \partial t_{c}}{\partial H / \partial B}=-\frac{\left[\frac{r}{r_{0}}-\left(1-t_{c}\right) \partial\left(\frac{r}{r_{0}}\right) / \partial t_{c}\right]}{-\left(1-t_{c}\right) \partial\left(\frac{r}{r_{0}}\right) / \partial B}
$$

The denominator is negative, since an increase in D will increase $r$ relative to $r_{0}$. Thus the whole expression will be positive if the numerator is positive. An increase in $t_{c}$, holding all security supplies constant, decreases the 
availability of tax-exempt income from shares, and this will induce high-tax-bracket investors to bid down $r_{0}$ relative to $r$. Nevertheless, if $t_{c}$ is approximately equal to $0.5, r / r_{0}$ would have to rise by about twice its original magnitude for the whole expression in (2) to be negative, and thus there is a strong presumption that increase in $t_{c}$ will be associated with increases in corporate debt. This exercise is represented diagrammatically in Figure 6. The increase in the corporate tax rate from $t_{c}$ to $t_{c}^{\prime}$ shifts the supply curve upward and brings about a higher level of corporate debt, $\mathrm{B}^{* \prime}$. Notice, however, that the increase in debt is dampened by the slope of the demand curve: the steeper is that slope, or, equivalently, the larger is the change in relative interest rates that is necessary to induce investors to absorb new bond issues into their portfolios, the smaller will be the change in $\mathrm{B}^{*}$.

If the increase in the corporate tax rate is accompanied by an increase in personal tax rates, $t_{p}$, on the other hand, the resulting change in corporate debt is given by

$$
\frac{\partial B}{\partial t_{c}}=\frac{-\left[\frac{r}{r_{0}}-\left(1-t_{c}\right) \partial\left(\frac{r}{r_{0}}\right) / \partial t_{c}+\frac{\partial\left(\frac{r}{r_{0}}\right)}{\partial t_{D}} \frac{d t_{p_{1}}}{d t_{c}}\right]}{-\left(1-t_{c}\right) \frac{\partial\left(\frac{r}{r_{0}}\right)}{\partial B}-}
$$

Since increases in $t_{p}$ increase the value of tax-exempt income to investors, $r / r_{0}$ would be expected to increase with $t_{p}$ and any 
increase in $B^{*}$ would be smaller than in the previous case where only $t_{c}$ increased. Diagrammatically, as shown in Figure 7 , the increase in $t_{p}$ rotates the demand curve upward from its intercept so that its slope is everywhere increased. If the increase in personal tax rates is of the same magnitude as the increase in corporate tax rates, it is even possible that the shifts in supply and demand will cancel one another out, leaving interest rates on bonds higher, but the equilibrium quantity of corporate debt roughly unchanged. 13

Another exogenous factor affecting $B^{*}$ is the inflation rate. Suppose the expected annual inflation rate suddenly jumps from zero to some positive amount, $i$. The nominal expected yields on taxable and tax-exempt securities, $r_{n}$ and $r_{\text {on }}$, which were previously equal to the real yields, ${ }_{r}$ and $r_{\text {or }}$, will now be given by

$$
\left(1+r_{r}\right)(1+i)=1+r_{n}
$$

and

$$
\left(1+r_{\text {or }}\right)(1+i)=1+r_{\text {on }},
$$

respectively. The effect of inflation on $\mathrm{B}^{*}$, starting from an initial equilibrium in which there is no expected inflation, is given by 


$$
\frac{\partial B^{*}}{\partial i}=-\frac{\partial\left(\frac{r\left(1-t_{c}\right)}{r_{0}}\right) / \partial i}{-\partial\left(\frac{r\left(1-t_{c}\right)}{r_{0}}\right) / \partial B}
$$

Using (4) and (5), this becomes

$$
\frac{\partial B}{\partial i}=-\frac{\frac{-r_{o}\left(1-t_{c}\right)\left(1+r_{r}\right)-r\left(1-t_{c}\right)\left(1+r_{o r}\right)}{\left(r_{0}\right)^{2}}}{\partial\left(\frac{r\left(1-t_{c}\right.}{r_{o}}\right) / \partial D},
$$

and using the equilibrium condition, $r\left(1-t_{c}\right)=r_{0}$, gives 14

$$
\frac{\partial B^{*}}{\partial i}=\frac{t_{c} / r_{0}}{\partial\left(\frac{r\left(1-t_{c}\right)}{r_{0}}\right) / \partial B}>0
$$

Diagrammatical1y, as shown in Figure 8 , the onset of inflation shifts the supply curve upward from $r_{\text {or }} / 1-t_{c}$ to $r_{\text {on }} / 1-t_{c}$, an upward shift of

$$
\frac{r_{\text {on }}-r_{o r}}{1-t_{c}}=\frac{i\left(1+r_{o r}\right)}{1-t_{c}}
$$


The demand curve also makes a parallel upward shift from $r_{\text {or }}$ to $r_{\text {on }}$, a difference of $i\left(1+r_{\text {or }}\right) \cdot{ }^{15}$ Thus the supply curve shifts up by more than the demand curve resulting in an increase in $\mathrm{B}^{*}$. 16

In the preceding three cases, shifts in the amount of corporate debt outstanding have been ultimately tax-induced. Even in the case of inflation, it is not some sort of "debtor-creditor" hypothesis 17 that explains the increase in corporate debt, but rather the interaction between inflation and taxes. In effect, inflation-adjusted interest rates allow some of the real principal on corporate debt to be deducted for tax purposes, and this increases the tax advantage to debt. 18

An additional feature of Miller's model is that exogenous changes in the supplies of other securities will also induce changes in $B^{*}$. An increase in the supply of tax-exempt bonds, $B_{0}$, for example, will result in the following change in corporate debt:

$$
\frac{\partial B^{*}}{\partial B_{0}}=-\frac{-\partial\left(\frac{r\left(1-t_{c}\right)}{r_{0}}\right) / \partial B_{0}}{-\partial\left(\frac{r\left(1-t_{c}\right)}{r_{0}}\right) / \partial B}
$$

Since an increase in $B_{0}$ increases $r_{0}$ relative to $r$, expression (10) will be positive. From a personal tax standpoint, tax- 
exempt bonds are substitutes for equity in Miller's model, and thus an increase in the supply of tax-exempts encourages corporations to shift their financing mix more toward debt.

An increase in the supply of (taxable) federal government bonds, $G$, on the other hand, has the opposite effect on $B^{*}$ :

$$
\frac{\partial B^{*}}{\partial G}=-\frac{-\partial\left(\frac{r\left(1-t_{c}\right)}{r_{o}}\right) / \partial G}{-\partial\left(\frac{r\left(1-t_{c}\right)}{r_{o}}\right) / \partial B}<0
$$

Again, from a personal tax standpoint, taxable government bonds are a corporate debt-substitute rather than an equity-substitute, and an increase in the supply of debt-substitutes induces corporations to shift their financing mix more toward equity.

These last two exercises emphasize the fact that the demand curve for corporate debt plays a special role in Miller's model. In the three other models discussed above, this demand curve is perfectly elastic, and thus investors are willing to freely substitute corporate debt for equity securities as long as their certainty-equivalent yields are equal. In effect, perfect elasticity stems from the perfect substitutes for corporate securities that can be created either on investors' own accounts or through financial intermediaries acting on their behalf. As long as perfectly elastic demands prevail, exogenous changes in the supplies of noncorporate securities will affect 
neither relative yields nor corporate financing decisions. In Miller's model, by contrast, differing tax treatment implies that different types of securities are imperfect substitutes and that the terms on which investors are willing to substitute one type of security for another differ across investors. This implies that exogenous changes in supplies of other securities will cause changes in relative yields and will in turn induce changes in the corporate financing mix. Taken together, the four theories reviewed in this section yield a number of possible determinants of changing patterns in the aggregate corporate capital structure. These include changes in corporate and personal tax rates and in the expected inflation rate, shifts in the perceived agency and bankruptcy costs associated with corporate securities, and exogenous changes in the supplies of noncorporate securities. In two respects, however, the picture seems incomplete.

First, these determinants of corporate financing patterns rely heavily on tax considerations. Apart from the tax rates themselves, the effect of inflation depends on its interaction with the tax system, and the effect of noncorporate security supplies rests on the fact that the tax system renders security demands less than perfectly elastic. While these tax-related determinants may have been important in recent years, they are incapable of explaining corporate financing patterns in the pre1913 era. In the absence of taxes, we are left with only agency costs to explain these patterns, and while agency costs may be 
an important determinant of cross-sectional variation in corporate capital structures, it is hard to imagine that these costs have shifted enough over time to cause major changes in the corporate financing mix. 19

Second, all of the four theories reviewed above rely on extreme assumptions about the supply curve for corporate debt, the demand curve, or both. In the Modigliani-Miller, tax savings - bankruptcy costs, and agency cost models, the demand curve is perfectly elastic, while in the ModiglianiMiller and Miller models, the supply curve is perfectly elastic. This perfect elasticity implies that substitution of debt for equity securities is costless either on the part of corporations (perfectly elastic supply) or individual investors (perfectly elastic demand).

On the demand side, at least, perfect elasticity is indicative of a well-developed capital market: that is one in which trading is competitive, transaction costs are low, investors are not subject to trading restrictions, and a full range of securities is available. While this vision of a well-developed capital market has proved to be a highly useful abstraction, however, it may be more appropriate when applied to short periods than to longer historical eras. Over long periods, economic forces would work toward making the capital market more perfect and more complete, and if one is interested in corporate financing trends over such periods, one is then 
interested in understanding what role the corporate sector has played in that process of capital market development. 21 As argued in Section I.A., a theory of the aggregate corporate capital structure should illuminate the interaction between the corporate sector and the other sectors of the economy as they respond to investors' demands for securities. Although perfectly elastic demands might emerge as a limiting case toward which forces tend over time, the theory seems incomplete if it does not explain the evolving role of corporate finance as the capital market develops.

C. Further Development of the Demand Side of Aggregate Capital Structure Theory

The effect of the security supplies and return-stream transformation possibilities afforded by other sectors of the economy will manifest itself primarily in the shapes and positions of the demand curves for corporate securities. A logical place to extend existing capital structure theories, then, is to attempt a richer development of the demand side. As we have seen above, demands for corporate securities are perfectly elastic in a complete and frictionless capital market. In Miller's (1977) model, on the other hand, the tax system and concomitant tax arbitrage restrictions on investors' portfolio choices cause the demand curve for corporate debt to be upward-sloping. Since these restrictions represent a 
kind of transaction cost, a natural extension of Miller's model would be to explore the ways in which other types of transaction costs would lead to upward-sloping demand curves.

In general, the presence of transaction costs implies that return streams from corporate securities cannot be costlessly transformed by individuals or financial intermediaries. To take an extreme case for illustrative purposes, let us suppose that return stream transformation (combining shareholdings with personal borrowing or lending, for example) is prohibitively costly at the individual investor level. Ignore for the time being the possible existence of financial intermediaries and assume that corporations start out relying solely on equity financing. Individuals, $i$, have initial endowments of cash, $y_{1}^{i}$, as well as initial fractional shareholdings, $\alpha^{i}$, in the aggregate market value of corporate equity, $V$. There is no second-period endowment, so individuals must make a consumptionsaving decision that maximizes the expected utility, $\mathrm{E}^{i}\left(\mathrm{U}^{\mathrm{i}}\right)$, of first and second-period consumption, $\mathrm{C}_{1}{ }^{i}$ and $\mathrm{C}_{2}{ }^{i}$. As noted above, however, the only available savings vehicle is holdings of corporate shares.

Firms in the aggregate are assumed to be subject to the same uncertainty, and thus the shares of one firm are viewed as perfect substitutes for those of any other firm. We will ignore distinctions among firms, then, and simply think of the corporate sector in the aggregate. The aggregate net income 
of firms in the second period is $\tilde{\theta} \bar{x}$, where $\tilde{\theta}$ is a random variable. In general, individuals may differ in their views of the distribution of $\theta$ and their subjective probability density functions will be denoted by $\mathrm{f}^{\dot{i}}(\tilde{\theta})$.

A representative individual's consumption-saving problem is

$$
\max _{\alpha} \int_{U^{i}}\left(C_{1}^{i}, \tilde{C}_{2}^{i}\right) f^{i}(\theta) d \theta
$$

where

$$
c_{1}^{i}=y_{1}^{i}+\left(\bar{\alpha}^{i}-\alpha^{i}\right) v
$$

and

$$
\tilde{C}_{2}^{i}=\alpha^{\tilde{\theta}} \bar{x}
$$

The first order condition is

$$
\frac{\partial U^{i}}{\partial \alpha^{i}}=\overline{\bar{x}} E^{i}\left(\tilde{U}_{2}^{i} \cdot \tilde{\theta}\right)-V E^{i}\left(\tilde{U}_{1}^{i}\right)=0,
$$

where

$$
E^{i}\left(U_{2}^{i} \tilde{\theta}\right)=\tilde{\theta}\left(\partial U^{i} / \partial C_{2}{ }^{i}\right) f^{i}(\tilde{\theta}) \mathrm{d} \theta,
$$

and 


$$
E^{i}\left(U_{1}^{i}\right)=\left(\partial U^{i} / \partial C_{1}^{i}\right) f^{i}(\tilde{\theta}) d \theta
$$

Using the fact that $\operatorname{cov}(\tilde{A})-E(\tilde{A B})-E(\tilde{A}) E(\tilde{B})$, where $\tilde{A}$ and $\tilde{B}$ are any two random variables, (15) may be written as

$$
V=\bar{x}\left(\frac{\mathrm{E}^{i}\left(\tilde{U}_{2}^{i}\right) E^{i}(\tilde{\theta})}{E^{i}\left(\tilde{U}_{1}^{i}\right)}+\frac{\operatorname{cov}\left(\tilde{U}_{2}^{i} \tilde{\theta}\right)}{E^{i}\left(\tilde{U}_{1}^{i}\right)}\right) .
$$

That is, each individual buys or sells shares until his personal valuation of corporate equity is exactly equal to the market's valuatior, $\mathrm{V}$.

As indicated by the right-hand side of (16), however, the individual's personal valuation has two components, which need not be equal separately for all individuals. If we assume away differences in expectations for the moment and let $E^{i}(\tilde{\theta})=1$ for all individuals, the first component $E\left(U_{2}^{i}\right) / E\left(U_{1}^{i}\right)$, (hereafter, tildes will be dropped for convenience), can be thought of as a personal discount factor for certain prospects and the second component can be thought of as a personal risk-adjustment factor. From (16), those investors with higher certainty discount factors (that is, those who place a higher value on certain future consumption) must have correspondingly larger (i.e., more negative) riskadjustment factors. 22

If we aggregate by summing (16), weighted by individual shareholdings, over all individuals, the result is 


$$
\sum_{i} \alpha^{i} V=V=\bar{x}\left(\sum_{i} \frac{{ }^{i} \frac{E\left(U_{2}^{i}\right)}{E\left(U_{1}^{i}\right)}}{E}+\sum_{i} \alpha \frac{\operatorname{cov}\left(U_{2}^{i} \Theta\right)}{E\left(U_{1}^{i}\right)}\right)
$$

and the cost of equity financing to the corporate sector may be expressed as

$$
\frac{\bar{X}}{\bar{V}}=\frac{1}{\sum_{i}^{i} \alpha^{i} \frac{E\left(U_{2}^{i}\right)}{E\left(U_{2}^{i}\right)}+\sum_{i}^{i} \frac{\operatorname{cov}\left(U_{2}^{i}\right)}{E\left(U_{1}^{i}\right)}} .
$$

That is, the cost of equity is determined by weighted averages of investors' certainty discount factors and risk-adjustment factors. Furthermore, since the second term in the denominator of (18) can be thought of as the overall market risk-adjustment factor, the market certainty-equivalent cost of equity, $r_{e}$, is given by

$$
r_{e}=\frac{1}{\sum \alpha^{i} \frac{E\left(U_{2}^{i}\right)}{E\left(U_{1}^{i}\right)}}
$$

If firms were now to begin substituting some debt financing for equity, ${ }^{23}$ those investors with highest certainty discount factors (that is, those placing the highest personal value on . this debt), would be the first to buy it. Since these investors 
would have higher-than-average certainty discount factors relative to the market as a whole, (19) indicates that firms could sell at least an initial increment of debt at a lower certainty-equivalent cost than that on equity. In effect, the corporate sector is able to gain by splitting off part of its total return stream, packaging this part in the form of riskless securities and selling them to the most risk-averse segment of the investing population.

As more corporate debt were sold, it would be purchased by investors requiring progressively higher certainty-equivalent yields. Thus we would have an upward sloping demand curve for corporate debt, just as in Miller (1977). In Miller's model, the upward slope is attributable to tax arbitrage restrictions, whereas here it is attributable to restrictions on individuals creating their own bonds, so in both cases demand is less than pefectly elastic because investors find it costly to transform corporate return streams on their own account. The supply curve, on the other hand, would be perfectly elastic at $r_{e}$, since transformation by firms is costless and thus firms would be willing to freely substitute debt for equity financing as long as their certainty-equivalent yields were the same. The resulting equilibrium is depicted in Figure 9, with corporations issuing that amount of debt, $B^{*}$, sufficient to drive the cost of debt, $r$, into equality with $r_{e}$.

As in Miller's model, the aggregate amount of corporate debt is determinate, but in equilibrium the capital structure decision 
is irrelevant at the individual firm level. Because of trading restrictions on investors, there is a demand for transformation services on the part of the corporate sector, and firms compete with one another to supply these services. Since all firms compete on equal terms, however, profits from financial transformation are squeezed out, and the most risk-averse investors reap a "bond-holders' surplus," just as those investors in the lowest tax brackets do in Miller's model.

Differences in investor expectations would play a similar role to differences in their attitudes toward risk in this model. If we held risk-adjustment factors constant across all investors in equation (16) but allowed expectations to vary (as represented by differences in $\mathrm{E}^{i}(\Theta)$ ), those investors who were most optimistic about the corporate sector's prospects (i.e., who had higher values of $\mathrm{E}^{\mathrm{i}}(\Theta)$ ) would have lower certainty discount factors. The most pessimistic investors, conversely, would be willing to accept the lowest return on corporate debt. The demand curve for corporate debt would thus be upwardsloping as before, and equilibrium would be reached when enough debt had been issued so that the marginal bondholder were exactly as optimistic about firm's prospects as the marginal shareholder.

In summary, then, it is investor characteristics such as risk-aversion and expectations, that drive the equilibrium corporate financing mix in this model. Loosely speaking, the 
larger is the segment of the investing population exhibiting high degrees of risk aversion and pessimistic expectations, the greater will be the amount of corporate debt. 24 In models with perfectly elastic demands for corporate securities, differences in these investor characteristics are capable of being exploited through financial transformations elsewhere in the economy, and hence they play no role in the determination of corporate capital structure. In the model presented in this section, by contrast, the sole purpose of issuing a mix of corporate securities is to exploit those differences.

The transaction costs that impart positive slope to the demand curve in this model are, of course, unrealistically severe. In practice, one would expect firms to face competition in their efforts to overcome transaction costs through financial transformation. Overcoming such costs and helping to satisfy divergent investor demands, in fact, is one of the primary rationales given for the existence of financial intermediaries.

In general, then, not only the corporate sector but also the financial intermediary and household sectors will have access to financial transformation technologies. To the extent that the corporate sector's technology exhibits cost advantages over those of other sectors, the corporate sector will tailor its financing mix to exploit these advantages. In this case, shifts in such investor characteristics as expectations and attitudes toward risk will be important determinants of changing patterns 
in corporate finance. To the extent that financial intermediaries or investors themselves can transform return streams at relatively low cost, on the other hand, demand curves for corporate securities will be highly elastic, and divergent investor characteristics will have little role in determining the corporate sector's financing mix. Moreover, it might be reasonable to suppose that the progression from the first case to the second would bear some relationship to the development of the capital market over time. In earlier times, when investors faced a less plentiful array of financial transformation opportunities, one would expect the intermediation role of corporate finance to be relatively important. As the capital market develops, however, and as investors come to rely less on corporations for financial transformation, this role would be expected to diminish.

To draw together some of the threads of Section I as a whole, the most general representation of the supply and demand for corporate debt would be one in which both curves exhibited less than perfect elasticity. This is depicted in Figure 10. 25 The shape of the supply curve will reflect such aspects of the corporate sector's transformation technology as bankruptcy costs, agency costs and the costs of issuing and servicing securities. The less important are these costs, the more elastic the supply curve will be. Moreover, the level of the supply curve will be determined by such factors as corporate taxes and - the expected inflation rate as well as the general level of 
real interest rates in the economy. The shape of the demand curve reflects the transformation technology available to investors, either on their own account or through financial intermediaries. The lower the costs of using this technology the more elastic the demand curve will be. Conversely, the higher the costs associated with this technology the less willing investors will be to freely substitute one type of corporate security for another. In this case investor expectations and attitudes toward risk, personal tax considerations, and supplies of competing securities (government bonds) will all affect the shape and position of the demand curve for corporate bonds.

This general representation of the supply and demand for corporate securities contains each of the theories reviewed in Section I.B. as a special case. It has the advantages that is does not rely solely on tax considerations to explain the corporate sector's financing patterns and that it is capable of taking into account the evolving role of the corporate sector in the financial system as a whole. Trends in the major determinants of corporate finance implied by the theory will be compared with the actual patterns in corporate financing over the course of the twentieth century to see which factors may have been most important. First, however, it is necessary to establish what those financing patterns have been. 


\section{Measurement of Capital Structure Trends}

Identification of the secular trends in corporate financing is hampered by a variety of measurement problems. Comparable data series often are not available over long periods of time. Accounting conventions are subject to change, and fluctuations in economic conditions, especially the rate of inflation, may destroy the comparability of accounting numbers between periods. Market value numbers may be used in their stead, but these must be estimated with some error, and it is unclear to what extent market values reflect the actual financing decisions of corporations and to what extent they reflect other exogenous factors.

The approach taken here will be to present a variety of different measures of corporate financing trends and to then try to infer the common patterns that emerge. Four different types of data have been used in previous studies of corporate financing and all four will be presented sequentially in the sections that follow. These include book value, market value, replacement cost and flow-of-funds data. Each type of measurement has its problems and advantages, and these will be discussed as the data are presented.

\section{A. Book Value Balance Sheet Data}

Perhaps the simplest approach to assessing corporate financing patterns is to examine changes in the composition of the liability side of the corporate balance sheet. This was the approach adopted by Miller (1963), for example, in a study undertaken for the Commission on Money and Credit. The Internal Revenue Service compiles balance sheet data for both 
U.S. corporations in the aggregate and for U.S. manufacturing corporations, and Miller's study examined these data for the period 1926-56. Using data through 1975, Table 1 presents a variety of balance sheet ratios from this source.

As Miller pointed out in his study, the ratios of longterm debt to total long-term capital remain impressively stable through the mid-1950's. They fluctuate somewhat, but virtually no trend is evident. The ratios of total debt (including liabilities of all kinds) to total assets show some tendency to rise in the late 1930 's and early 1940 's but exhibit no trend, thereafter until at least the late '50's. ${ }^{26}$ The use of preferred stock, on the other hand, exhibits a steady secular decline through the early $1960^{\prime}$ s. $^{27}$

Data that was not available to Miller at the time of his study, however, suggest that debt ratios have tended to drift steadily upward since the late 1950's. This may indicate a fundamental change in corporate financial policy, although Miller (1.977) has warned that at least some of this apparent trend may be spurious. Liberalized depreciation allowance since the early 1960 's, for example, would tend to depress reported equity values and would automatically tend to increase debt ratios. By the same token, inflation in the 1960's and 1970's may have caused reported asset values to be understated, thus giving a misleading impression of the size of corporate debt relative to assets. ${ }^{28}$

If capital markets are efficient, investors should see through these accounting changes and should also adjust for the 
effects of inflation. ${ }^{29}$ In an attempt to circumvent these problems, then, we turn next to balance sheet ratios in market value terms.

B. Market Value Balance Sheet Data

Since market value data are not available for the nonfinancial corporate sector as a whole, they must be estimated. A variety of estimates using somewhat different techniques is presented in Table 2.

The most common approach is to take dividend and interest payments reported by corporations and to capitalize these at appropriate rates to obtain estimates of the market values of equity and debt respectively. This approach has been followed by Holland and Myers (1979), using the dividend yield on the Standard and Poor's Composite Index and Moody's Baa corporate bond rate as capitalization rates. Their estimates, updated through 1979, are shown in column (1) of Table 2. Like the accounting numbers in Table 1, these estimates suggest that there has been a considerable increase in corporate debt ratios since the late $1950^{\prime \prime} \mathrm{s}$. A major portion of this increase has apparently occured during the decade of the '70's. The increase is not nearly as smooth as the accounting numbers suggest, however, as dips occur in the early and late 1.960's and again in the early and late '70's. Furthermore, although the 1930's and '40's might hardly be characterized as a normal period the estimates at least suggest that the debt ratios occurring in the 1970's are by no means unprecedented. 
The estimates in columns 2 and 3 are from von Furstenberg (1977) and they differ in two respects. First, dividend payments for common and preferred stock have been separated and capitalized at different rates. Second, von Furstenberg argued that the weighted average rating of corporate bonds outstanding has tended to be A or slightly better. He thus capitalized interest payments using the A-rated bond yield and also - attempted to take into account the maturity composition of corporate debt. His estimates give consistently higher values for corporate debt ratios than those of Holland and Myers, partly because of the lower capitalization rate for corporate debt and partly because the higher dividend yield on preferred stock gives a lower estimate for the combined market value of common and preferred stock. Nevertheless, the two series move in unison and von Furstenberg's estimates suggest a considerable rise in corporate debt ratios since the mid-1950's and the same higher plateau in the $1970^{\prime} \mathrm{s}$. The estimates also reveal that the relative value of preferred stock has remained low throughout and has generally tended to decline, with the exception of a modest comeback in the mid-1970's.

A third approach has been followed by Gordon and Malkiel (1981), who use the sample of nonfinancial corporations for which data is reported on the Standard and Poor's Compustat Tapes. Market values of common equity can be observed directly for these companies. Market values of debt and preferred stock have been 
estimated using methods similar to von Furstenberg's but with the estimates derived from bond and preferred stock prices sampled at the two-digit industry level. Again, the estimated debt ratios, shown in column 4 of Table 2 , move in parallel with the other two series, with their absolute magnitudes generally falling between the other two. The estimates suggest the same increase in debt ratios, particularly since the late 1950's. Since both the von Furstenberg and the Gordon and Malkiel estimates range over a shorter period than those of Holland and Myers, however, they may give the impression that current debt ratios are higher by historical standards than is really the case.

The last approach to estimating market values, followed by Ciccolo (1981), uses observed market values for all securities for samples of roughly fifty U.S. manufacturing firms. Ciccolo has reported market value balance sheet ratios for the aggregate of his sample firms for selected years, and these are shown in the last two columns of Table 2. The debt ratios are generally much lower than those in the other series and do not move in parallel with the Holland and Myers estimates for the early years. The fact that the debt ratios are so much lower for all years suggests that the sample may not be representative of the nonfinancial corporate sector as a whole. Nevertheless, Ciccolo's figures reveal the same increase in debt ratios since the 1960's that the other series do. Moreover, the preferred stock figures 
confirm the secular decline in the importance of preferred stock that appears in the accounting data of Table 1 .

\section{Replacement Cost Data}

Another ratio that has been used in previous studies to measure corporate leverage is that of the market value of debt to the replacement value of total assets. On theoretical grounds, this ratio may be a better measure than those in Table 2 of how much debt firms have relative to their debt capacity. 30 Furthermore, measuring assets at replacement cost alleviates the overstatement in book value ratios during inflationary periods that results from the understatement of corporate assets. In any case, estimates of the ratio of the market value of debt to the replacement value of assets are available over a long period.

Two series of these ratios are available. One is from von Furstenberg's (1977) study and runs annually from 1952 to 1976 , while the other is from Goldsmith's (1963) study of national balance sheets. Goldsmith's estimates are available for selected years from, 1900 to 1945 and annually from 1945 to 1958. The two series are shown in Table 3. The figures from. Goldsmith suggest that nonfinancial corporations' use of debt financing relative to the replacement value of their assets was markedly lower in the decade following World War II than it had been earlier in the century. The figures from von Furstenberg indicate that, after remaining essentially flat for 
much of the 1950's, corporate debt ratios began a gradual but steady rise that carried through the late 1970's.

It can be seen from the years of overlap in the 1950's that there are some discrepancies between the two series. The ratios derived from Goldsmith's data, for example, are consistently somewhat lower than von Furstenberg's. ${ }^{31}$ Moreover, Goldsmith's series itself may not give comparable data between pre-war and postwar periods. Balance sheets from the pre-war period are from Goldsmith's A Study of Saving in the United States (1958) while the annual data from 1945 to 1958 are from his Studies in the National Balance Sheet of the United States (1963). Some changes in sectoral definitions and estimation methods occurred between these two studies, and the only year of overlap, 1945, indicates that these changes may have caused some differences in the debt ratios.

Nevertheless, some tentative conclusions can be drawn. Between 1952 and 1958, Goldsmith's and von Furstenberg's series move quite closely together, and it may be that they would exhibit similar trends throughout the whole period 1900-1978. If so, it appears that even though corporate debt ratios increased substantially in the postwar period, particularly from the mid 1950's to the mid $1960^{\prime}$ 's, the debt ratios of recent years are not unusual by historical standards. Even if it is argued on the basis of the two 1945 estimates that the pre-war figures are overstated by a third, the debt ratios of the 1960's and 1970 's would still 
represent a return to roughly the levels that prevailed over the pre-war period. The replacement value data, then, provides some further support for the impression gained from market value data that, while debt ratios have increased in recent decades, after a relatively flat period in the 1940's and '50's, they are nevertheless not unusual by prewar standards.

\section{Flow of Funds Data}

The final method for measuring corporate financing patterns makes use of flows of funds over periods of time as opposed to stocks at particular dates. While this method does not take into account valuation changes, as market value and replacement value estimates do, it may nevertheless come closest to recording the actual decisions made by corporations. Furthermore, since capital consumption allowances are included as a component of internal equity financing, this method is not subject to Miller's criticisms about understatement of equity financing in the wake of changes in depreciation accounting.

Between Goldsmith's Study of Saving data, which run from 1900-45, and the Federal Reserve Flow of Funds Accounts which cover the period 1946 to the present, it is possible to put together a fairly lengthy record of corporate financing flows. The data are shown in Table 4. Since the emphasis of this paper is on secular patterns in corporate finance, the flows are divided into periods covering roughly a decade each. 
The same data have previously been examined by Kuznets (1961), Sametz (1964) and Friedman (1980). Kuznets and Sametz were limited to the period 1900 through the late 1950's. Both were struck by the sharp decline in the use of stock issues as a financing source and both argued that internal funds, disregarding the aberrant years of the Depression and World War II, had shown at least a modest upward trend relative to other financing sources. Both authors also pointed out that, although short-term liabilities fluctuated considerably, they generally increased relative to both total financing sources and total debt through the late $1950^{\prime} \mathrm{s}$. Finally, Sametz emphasized that despite trends in internal funds and external equity and in shortterm and long-term debt, the use of total debt financing relative to total equity financing appeared to have remained roughly constant over long periods of time.

Friedman, confining his attention to the postwar period, pointed out that internal funds first increased relative to total sources in the 1950 's and then decreased in the '60's and '70's. He also emphasized the continued decline in stock issues, an increased use of debt, and in the 1ate '60's and '70's an increase in the use of short-term debt.

Looking at the whole period, as shown in the data in Table 4 , the trends discussed by all three authors are evident, and at the same time somelonger-run trends come into sharper focus. It is clear, for example, that the use of debt financing has increased in the 1960's and 1970's after recovering in 
the years following World War II to pre-Depression levels. Use of long term debt, however, is by no means unusual, even after steady postwar increases, relative to the levels prevailing in the first decade of the century and in the 1920's. The increased use of debt, then, seems largely attributable to an increase in short-term liabilities. It should also be noted that short-term liabilities have shown considerable fluctuations over time, with substantial increases occurring in the 1913-22 period and again during the World War II years. Although it cannot be denied that short-term liabilities have been much higher in the postwar period than in the pre-war years, it is not clear if the recent surge represents a temporary phenomenon or the continuation of a trend.

On the equity side, the greatly diminished use of stock issues appears to be a long-term trend. Stock issues staged a modest comeback in the $1970^{\prime}$ s, compared with the 1960 's, but they remain very low by pre-war standards. As has been widely noted, internally generated funds have also declined relative to total sources during the postwar period. The data indicate, however, that the depressed levels of internal funds experienced in the $1970^{\prime} \mathrm{s}$ are not unusually low relative to the levels of the first decade of the century and the 1920's. It might be inferred, instead, that the use of internal funds was unusually high during the period 1930-1960 and that the past two decades have witnessed a return to roughly the levels experienced during the pre-Depression era. 


\section{E. Common Trends}

Viewing the different measures of corporate financing patterns simultaneously, some common threads appear. First, the use of debt financing has increased considerably in the postwar period, particularly in the $1960^{\prime}$ 's and ' $70^{\prime} \mathrm{s}$. This trend emerges regardless of the method of measurement employed. There is considerably more doubt, however, as to whether current debt levels are unusually high relative to those of the prewar period. The accounting-based data of Tables 1 and 4 suggest that they are, but the measures that make some attempt to correct for valuation changes, as shown in Tables 2 and 3 , indicate that this may not be true. At the very least, the trend in corporate debt ratios has not been unindirectional. Rather, these ratios appear to have been somewhat low in the 1920 's and especially in the years surrounding World War II. Thus the postwar surge in corporate debt does not appear to be as dramatic when viewed in the light of the whole century's experience as it does when the postwar period is considered in isolation. Second, some changes have occurred within the debt and equity components of corporate finance. Although it is traceable only in the sources and uses of funds data, there appears to be little doubt that short-term liabilities have increased in importance over time. Again, however, the trend is not unidirectional. Within the equity component, there is no doubt that issues of both preferred and common stock have declined considerably in relative importance. Internally generated equity 
on the other hand is currently low relative to the previous few decades, but whether it is unusually low when a longer-run view is taken is far less clear.

\section{Interpretation of Capital Structure Trends}

Having reviewed the secular patterns in various measures of corporate financing activity, the remaining step is to interpret these patterns in the light of the theory developed in Section I. This interpretation will be drawn from a comparison of the trends in corporate capital structure's determinants, as suggested by the theory, with the capital structure trends themselves. The primary determinants that can be readily traced are corporate and personal tax rates, the rate of inflation, the relative supplies of substitutes for corporate securities, and the extent of financial intermediation in the economy. These will be examined in turn in the paragraphs that follow.

This paper should be regarded as a preliminary attempt to link theory and evidence, and this section does not contain a rigorous empirical test of the theory. It is hoped, in fact, that the empirical regularities discussed here will stimulate further refinement of an aggregate corporate capital structure theory. Nevertheless, existing theories are assessed in terms of their ability to explain these regularities.

\section{A. Corporate and Personal Tax Rates}

As was seen in Section I, tax considerations are an important element of capital structure determination in both the tax 
savings-bankruptcy costs and Miller (1977) models. They would also play a role, though not necessarily the preeminent one, in the more general supply-and-demand model with which Section I concluded.

Movements in marginal corporate and personal tax rates from 1913 to the present are shown in Table 5. Personal tax rates for those investors in the lowest and highest marginal brackets are shown in columns (1) and (2), respectively, while the corporate tax rate is shown in column (3).

The implications of these rates for corporate financing decisions may perhaps be drawn more sharply if we compute what Grier and Strebel (1980) have referred to as the "net debt incentive tax ratios," $\delta$, for investors in the lowest and highest tax brackets. This ratio is defined as

$$
\delta=1-\frac{1-t_{c}}{1-t_{p B}} \text {, }
$$

where $t_{c}$ is the corporate tax rate and $t_{\mathrm{pB}}$ is the personal tax rate on ordinary income. ${ }^{33}$ Columns (4) and (5) of Table 5 give time series for $\delta_{L}$, the debt incentive tax ratio for investors in lowest tax bracket, and $\delta_{H}$, the ratio for investors in the highest bracket, respectively.

Expression (20) indicates that $\delta$ will be positive for investors in tax brackets lower than $t_{C}$ and negative for investors in tax brackets higher than $t_{c}$. In effect, low tax- 
bracket investors will prefer to borrow through corporations so as to maximize the tax advantage of debt, and conversely, high tax-bracket investors will prefer to borrow on their own account. 34 Looking at values of $\delta$ for investors in the lowest and highest tax brackets, then, gives some idea of the strength of the demand for corporate leverage from low taxbracket investors and of the aversion to corporate leverage on the part of high tax-bracket investors. ${ }^{35}$ Inferences must be limited, of course, without further knowledge of the distribution of wealth generally and shareholdings in particular among investors in different tax brackets. Nevertheless, one would expect that if $\delta$ values tend to increase over time for both high and low tax-bracket investors, the demand for corporate leverage would also increase. In addition, during times when $\delta$ values are small, even for low tax-bracket investors, one would expect that any tax advantage to corporate debt would be more easily offset by such factors as bankruptcy and agency costs.

Turning to the values of $\delta$ in Table 5 , the tax code apparently gave little or no incentive for corporate leverage in the early years of its existence. Until the early 1920's, even investors in the lowest tax brackets had little incentive, purely from a tax standpoint, to hold shares in levered firms, while high tax-bracket investors often incurred a substantial tax disadvantage from corporate leverage. During the 1920's this tax disadvantage for high tax-bracket investors grew much 
smaller, but at the same time the tax advantage for low taxbracket investors remained small. It was not until the 1940's, when corporate tax rates rose dramatically, that the $\delta$ values grew very much for low tax bracket investors. From 1940 to 1954, these $\delta$ values for low tax-bracket investors approximately doubled, whereafter they have remained essentially unchanged to the present. Since top-bracket personal tax rates were very high in the 1940's and 1950's, the o values for high-bracket investors were also very negative during this period. These $\delta$ values have become less negative in the 1960's and 1970's.

Overall, then, it can be inferred that the tax system should have given rise to a demand for corporate leverage on the part of at least a segment of the investing population. This demand should have shown particular growth, moreover, between the 1920 's and the early 1950's. In addition, the less negative values of $\delta_{\mathrm{H}}$ from the mid-1960's to the present may indicate an atmosphere more conducive to corporate debt in recent years. Comparing these trends with those discussed in Section II, however, it is apparent that tax considerations are not the sole determinant of patterns in corporate sector financing. Although the values of $\delta_{L}$ were small immediately following the advent of the income tax system, they roughly doubled in the 1920's, again in the 1930's and again in the 1940's. Despite the apparent increase in the demand for corporate leverage, however, the tables in Section 2 indicate that corporate debt usage fell for at least the first two decades following 1913 and that 
it remained low at least through World War II. The increases in both $\delta_{\mathrm{L}}$ and $\delta_{\mathrm{H}}$ that have occurred since the 1940's are broadly consistent with increased corporate leverage that has occurred since that period, but the two trends are not closely synchronized. $^{36}$ According to Tables 2 and 4 , the largest increases in corporate debt financing appear to have occurred during the 1970's, for example, whereas the debt tax incentive ratios have been relatively flat during that time.

\section{B. Perceived Bankruptcy Costs}

If the tax system alone is not sufficient to explain the patterns in corporate financing, some supplementary determinants must be invoked. One possibility is perceived bankruptcy costs. There is some plausibility, for example to the notion that increased tax incentives for corporate debt in the late 1930's and early '40's were overwhelmed by a tremendous increase in perceptions of bankruptcy risk in the wake of the Depression. In a similar vein, Gordon and Malkiel (1981) point to the figures in Table 2 and argue that increased economic instability since 1974 has again increased perceptions of bankruptcy risk, causing corporations to retreat somewhat in their use of debt financing. Bankruptcy costs have the disadvantage, however, that they cannot ben measured with any precision, and the timing of any shifts is especially hard to pin down. One might wonder why bankruptcy fears would not have been allayed sooner following the Depression, especially in view of the increased tax incentives 
for debt. Moreover, one might ask why corporate debt financing was apparently relatively small in the 1920's, even though tax incentives increased and investors are generally believed to have been unusually optimistic about firms' prospects.

C. Inflation

Another supplementary factor is the inflation rate. As discussed in Section I, inflation can enhance the real tax advantage to debt, and thus the interaction between taxes and inflation may produce an explanation of corporate financing patterns that is superior to that of taxes alone.

Some idea of inflation trends can be gained from the yearly percentage changes in the implicit GNP price deflator, shown in Table 6 for the years 1901 to the present. ${ }^{37}$ From these it might be concluded that the relatively high inflation rates of the late 1960's and the 1970's interacted with relatively high debt tax incentive ratios to produce an increase in corporate debt financing during this period. There was also a temporary increase in corporate debt usage coinciding with both the increase in debt tax incentive ratios and the inflationary burst of the immediate post-World War II years. ${ }^{38}$ Earlier, however, the years surrounding World War I were also years of relatively high inflation rates coupled with rising debt tax incentive ratios (at least for investors in low tax brackets). The data in Section II indicate, though, that corporate debt financing was lower in that decade than in the one preceding it. Again, 
therefore, although the interaction between taxes and inflation probably contributed to increased debt usage in recent years, it does not appear to be the sole determinant of corporate financing patterns.

D. Supplies of Substitute Securities and the Evolution of the Financial Intermediary System

It will be recalled from Section I that changes in relative security supplies or in the extent of financial intermediation played no role in models with perfectly elastic demands for corporate securities. In the more general model with costly financial transformation, however, these factors can affect the portfolio opportunities available to investors and hence the equilibrium yields and quantities of corporate securities.

Some idea of the relative position of corporate debt in the economy may be gained from Table 7 , which shows the total liabilities of the nonfinancial corporate, federal government, state and local government and financial institution sectors as well as the mortgage liabilities of the household sector, al1 expressed as percentages of total domestic liabilities outstanding. Data are available from Goldsmith (1963) for selected years from 1900 to 1945 and annually from 1945 to 1958. Annual data are also available from the Federal Reserve Flow of Funds Accounts for the years 1945-'78. The series for U.S. government debt and household mortgage debt are intended to reflect supplies of securities that might act as close substitutes for corporate 
debt in investors' portfolios. ${ }^{39}$ As indicated in one of the comparative statics exercises in Section I, the supply of state and local government debt acts, from a tax standpoint at least, as a substitute for corporate equity. Finally, the series on financial institution liabilities is intended to serve as a rough index of the strength of the financial intermediary system. As indicated in section I, the importance of corporate finance as an intermediation device may be conditioned by the development of this system.

The data suggest that in the post-World War II years, corporate liabilities have been much smaller relative to total liabilities than in the pre-Depression era. There has also been little if any trend in the share of corporate liabilities since the 1950's. While the data in Tables $1-4$ indicate that corporate debt financing has increased relative to equity since that time, therefore, corporate debt has still only kept pace with the postwar expansion in liabilities for the economy as a whole. The share of corporate liabilities dropped sharply during the Depression and World War II before recovering somewhat during the years 1945-'50. Since that time a modest upward trend seems to have occurred through the mid-1970's followed by a mild decline.

Liabilities of the federal government by contrast, were quite small at the beginning of the century and remained so until the Depression, even including the increase surrounding World War I. During the Depression and especially during World 
War II, however, federal government debt mushroomed relative to that of the other sectors of the economy. Thereafter, it declined steadily before reaching an apparent plateau around 1970.

On the whole, state and local government and household mortgage liabilities have been smaller than those of the corporate and federal government sectors. State and local government debt has remained relatively small throughout, with the highest plateau being reached in 1960's and early '70's. Household mortgage debt hovered around five percent of total liabilities in the pre-Depression era, before falling somewhat by the end of World War II. 40 since then it has increased at a slow but steady pace and in recent years household mortgage debt has been larger than that of the federal government and only slightly smaller than corporate liabilities.

Finally, the share of financial institution liabilities appears to have followed a secular upward trend. An increase seems to have occurred in the late $1930^{\prime} \mathrm{s}$, although there is some conflict between the Goldsmith data and the Flow of Funds data as to whether this represented a dramatic upward shift. After remaining steady between 1945 and 1960, the share of financial institution liabilities again appears to have begun increasing in recent years, albeit at a relatively slow pace.

The theory in section I suggests that if the demand curve for corporate debt is not perfectly elastic, exogenous increases in the supplies of substitute securities will reduce 
the equilibrium amount of corporate debt. Broadly speaking, this proposition appears to receive some support from the data in Table 7. Particularly in the first half of this century, the share of corporate liabilities has tended to move in the opposite direction from that of federal government liabilities. At the same time that federal government debt was taking its great upward leap during the Depression and World War II, for example, the share of corporate liabilities declined dramatically, as did the share of debt in total corporate financing. Similarly, in the immediate postwar years the share of corporate liabilities staged a modest recovery, and corporate debt financing increased relative to equity, at the same time that the share of government liabilities was declining. Corporate debt financing generally continued to increase relative to equity from the 1950's through the present at the same time that the share of federal government liabilities has continued to fall.

There are some points at which the data and the theory do not coincide exactly. Little can be inferred, for example, about the relationship between corporate financing patterns and movements in state and local government liabilities or household mortgage liabilities. If anything, the share of corporate liabilities seems to have moved in the same direction as that of household mortgages. 41 Moreover, corporate debt financing has shown its largest increases of the postwar years during the 1970's, a time when the relative supply of government securities has been essentially flat. 
Nevertheless, the effect of relative security supplies shows at least enough promise to warrant further investigation in future work. 42 The potential explanatory power of this factor seems particularly great during the early decades of the century when tax considerations were non-existent or of lesser importance. In addition, substitution relationships may have some bearing on aspects of corporate finance, such as the maturity structure of debt, that are unrelated to tax considerations. 43

It is more difficult to formulate precise hypotheses about the effect of financial intermediation on corporate finance. It seems clear that the development of the financial intermediary system facilitates corporate external financing by making it easier for new issues of corporate securities to be absorbed by the capital market. It is less obvious, however, whether the system's capacity to absorb these issues would favor debt financing over equity by corporations or vice versa.

To the extent that corporate securities themselves play the role of an intermediary between the characteristics of firms' real assets and investors' portfolio needs, the scope for that role would seem greatest when the system of financial intermediaries is less highly developed. In particular, investors may have limited access to relatively safe securities at such times and thus their demand for corporate debt may be high. A tentative interpretation of the data in Table 7 that is consistent with corporate securities playing an intermediary role, then, is as follows: In the earlier decades of the century, corporations 
may have played a more substantial intermediary role than has been true in recent decades. Investors' demands for relatively safe, fixed-dollar claims were not met to such a degree in the earlier decades by either the government or financial institutions as has been the case in more recent times. These factors may help account both for the relatively high proportion of debt in total corporate financing and for the relatively high proportion of corporate debt in total domestic liabilities in the early part of the century. In the years following the Depression, however, this intermediary role of corporate debt has probably been reduced, both by increased relative supplies of federal government and household mortgage debt and by the increased extent of financial intermediation. 44

By the present time, both the market for corporate debt and for corporate stock have become heavily institutionalized and it would be much more difficult to describe convincingly an overt intermediary role played by these securities. Still, certain shifts in corporate financial structure may at times be linked to shifts in the costs of financial intermediation. It is widely held, for example, that recent interest rate volatility has made it increasingly dangerous for financial institutions to intermediate between long-term financial assets and shortterm liabilities. This may account in part, then, for the shift in corporate liabilities toward increasingly short maturities. ${ }^{45}$

\section{E. Summary and Conclusions}

Overall, it has been argued in this paper that in order to explain the secular patterns in aggregate corporate financing, 
it is necessary to employ a theory explicitly aimed at the aggregate corporate capital structure. The outline for such a theory has been developed here, building on previous theoretical contributions, and containing those contributions as special cases. The feature of this theory that is somewhat novel is the emphasis on the costs of financial transformation and hence on the role of corporations as intermediaries. It has been argued, then, that in addition to such factors as taxes, inflation and perceived bankruptcy costs, the supplies of substitute securities and the development of the financial intermediary system may exert an important influence on corporate financing behavior. A preliminary examination of available data confirms the trend cited in other studies toward greater use of debt financing by corporations in the post-World War II period. Nevertheless, the evidence suggests further that corporate reliance on debt financing was unusually low around World War II and that current debt proportions may not be entirely out of line with those experienced in the earlier decades of the century.

Since the study encompasses periods when the tax system was non-existent, tax considerations alone seem incapable of explaining these overall trends. Rather, the explanation suggested here is that nonfinancial corporations played a more substantial intermediary role in the early decades of the century and that corporate debt helped satisfy investors' demands for relatively safe securities. That intermeidary role diminished by the end of World War II in the face of rising federal government debt and the continued development of financial institutions, and 
corporations as a whole may now have relatively little comparative advantage in performing financial transformations. Nevertheless, tax rates and inflation in the postwar years have combined with the declining relative size of federal government debt to stimulate corporate debt financing again. Although corporate debt has never approached its earlier importance relative to total domestic liabilities, corporations' reliance on debt financing relative to equity has returned, by some measures at least, to roughly the proportions experienced in the early part of the century.

It is clear that many details remain to be filled in here. In particular, if the costs of financial transformation are an important element in the corporate sector's financing behavior, one would like a better understanding of these costs and of where, specifically, corporations might be expected to possess a comparative advantage over financial institutions and individual investors. In addition, hypotheses should be developed about the ways in which technological and regulatory changes affect these comparative advantages. ${ }^{46}$ On the basis of the data examined in this paper, further development of an aggregate capital structure theory along the lines suggested here appears to offer some promise for explaining the secular patterns in corporate finance. 


\begin{tabular}{r|l} 
Nonfinancial Corporations \\
Plant and & Bank Loans \\
Equipment & \\
Inventories & Bonds \\
Bank Deposits & Equity Shares
\end{tabular}

\begin{tabular}{r|l} 
& \multicolumn{1}{c}{ Financial } \\
${ } }$ & Deposits \\
Corporate Bonds & Insurance \\
Corporate Shares & Pension Obligations \\
Mortgages & Equity Shares \\
Consumer Credit &
\end{tabular}

Households

\begin{tabular}{r|l} 
Houses & Consumer Debt \\
\hline Consumer Durables & Mortgages \\
Corporate Bonds & Net Worth \\
in Corporations and & \\
Pancial Institutions \\
Deposits \\
Insurance
\end{tabular}

Figure 1

Balance Sheets of the Three Sectors in a Hypothetical Economy 


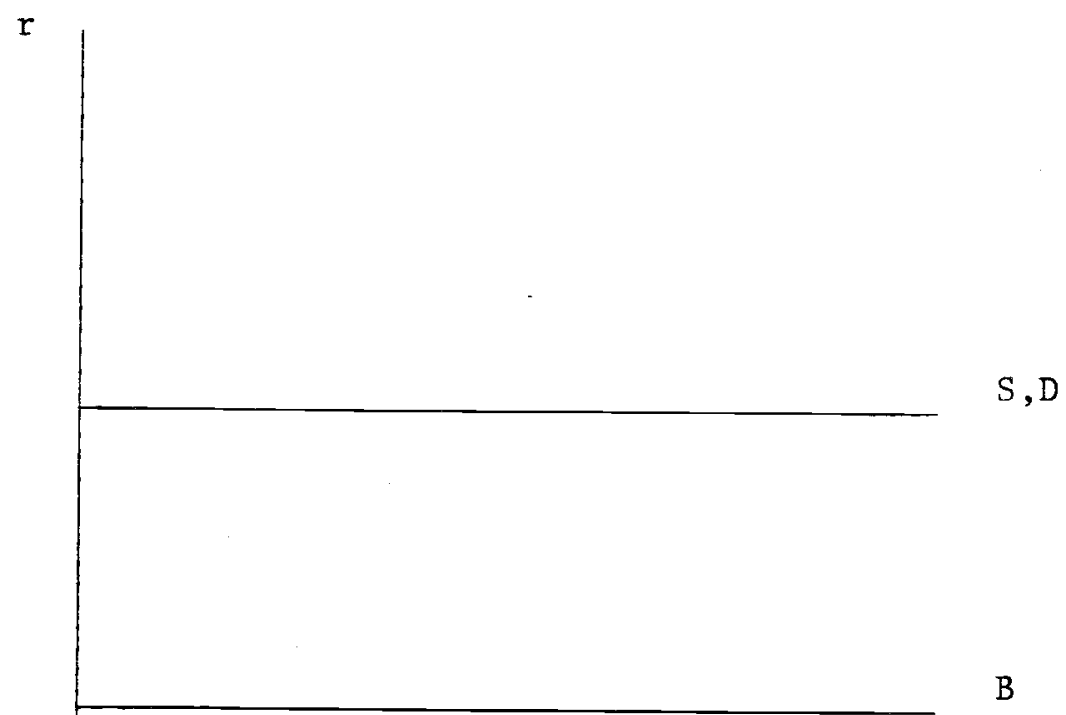

Figure 2

Supply, S, and Demand, D, for Corporate Debt Implied by Modigliani and Miller (1958). 


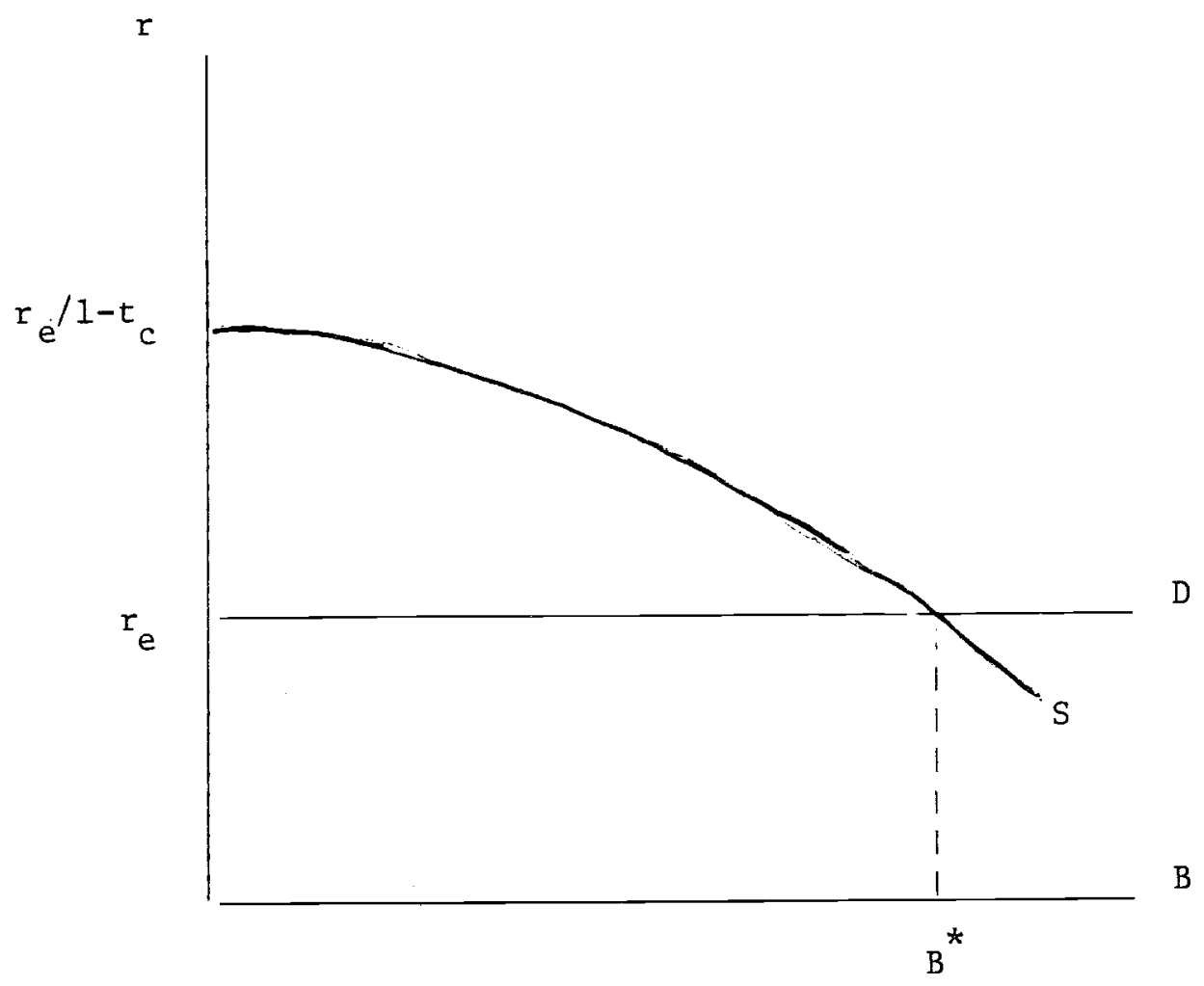

Figure 3

Supply and Demand for Corporate Debt Implied by the Tax Saving-Bankruptcy Cost Theory. Equilibrium Amount of . Corporate Debt is B. 


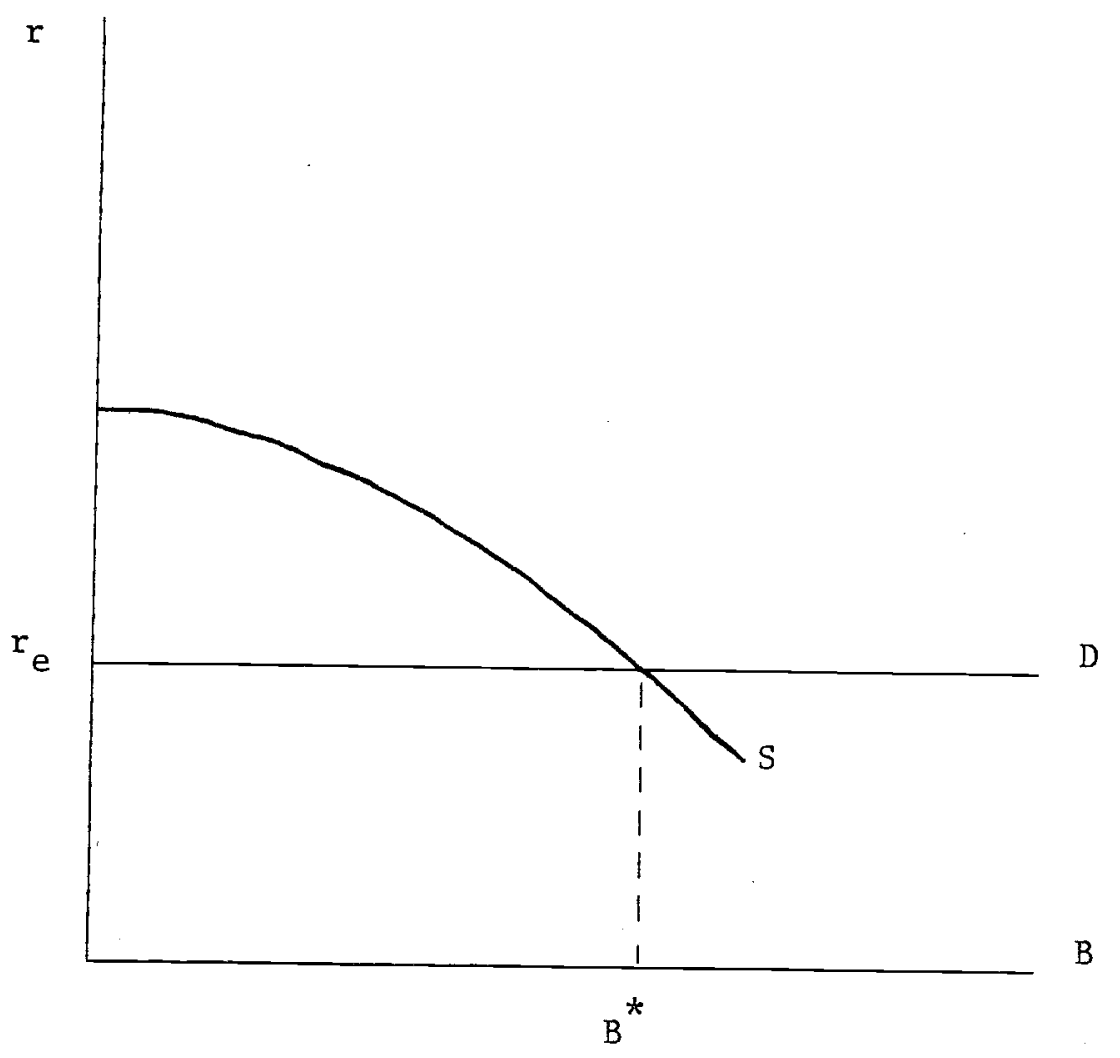

Figure 4

Supply and Demand Curves for Corporate Debt Implied by the Agency Cost Theory of Jensen and Meckling (1976). 


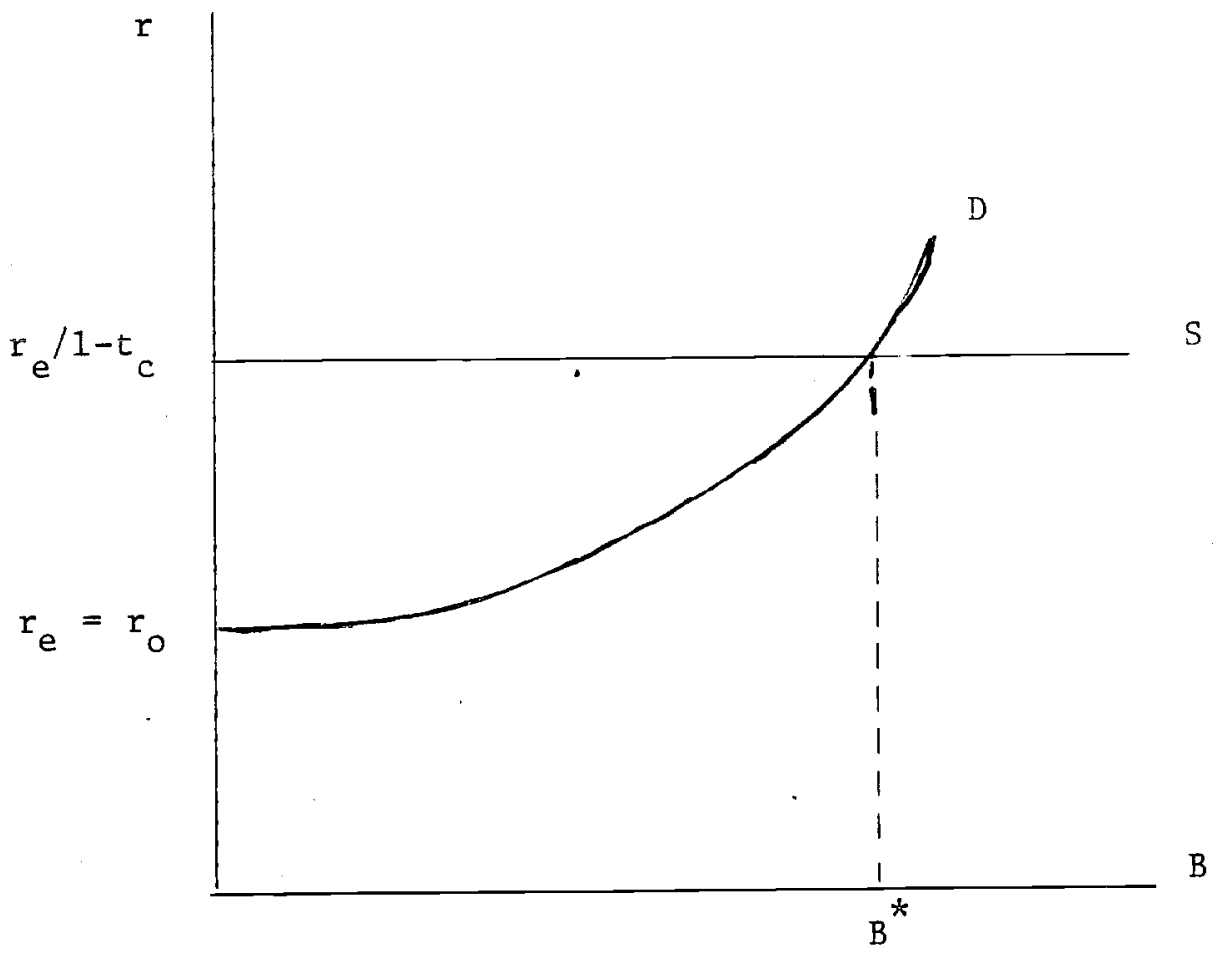

Figure 5

Supply and Demand for Corporate Debt Implied by Miller (1977). 


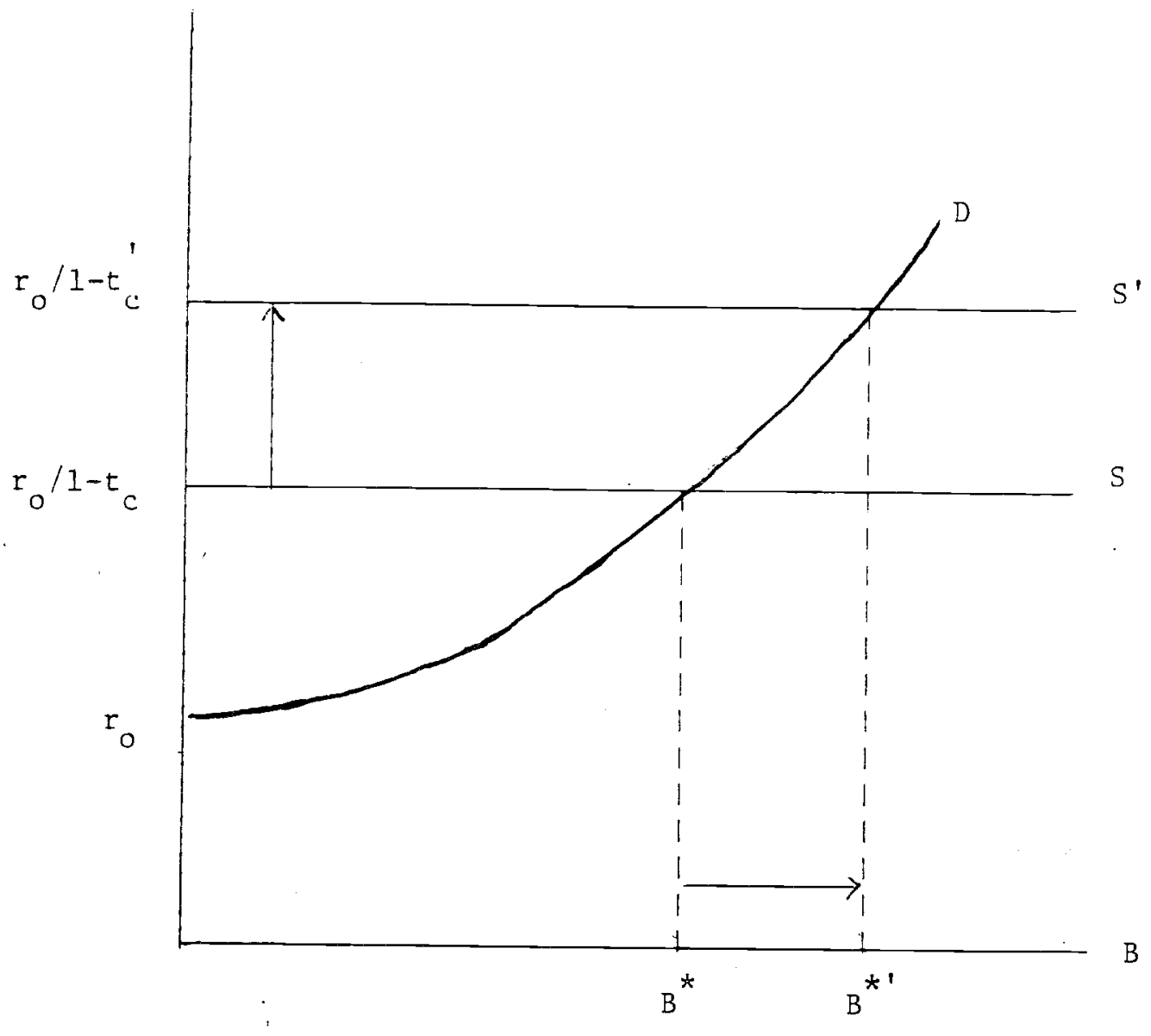

Figure 6

Change in Equilibrium Quantity of Corporate Debt Caused By an Increase in the Corporate Tax Rate 


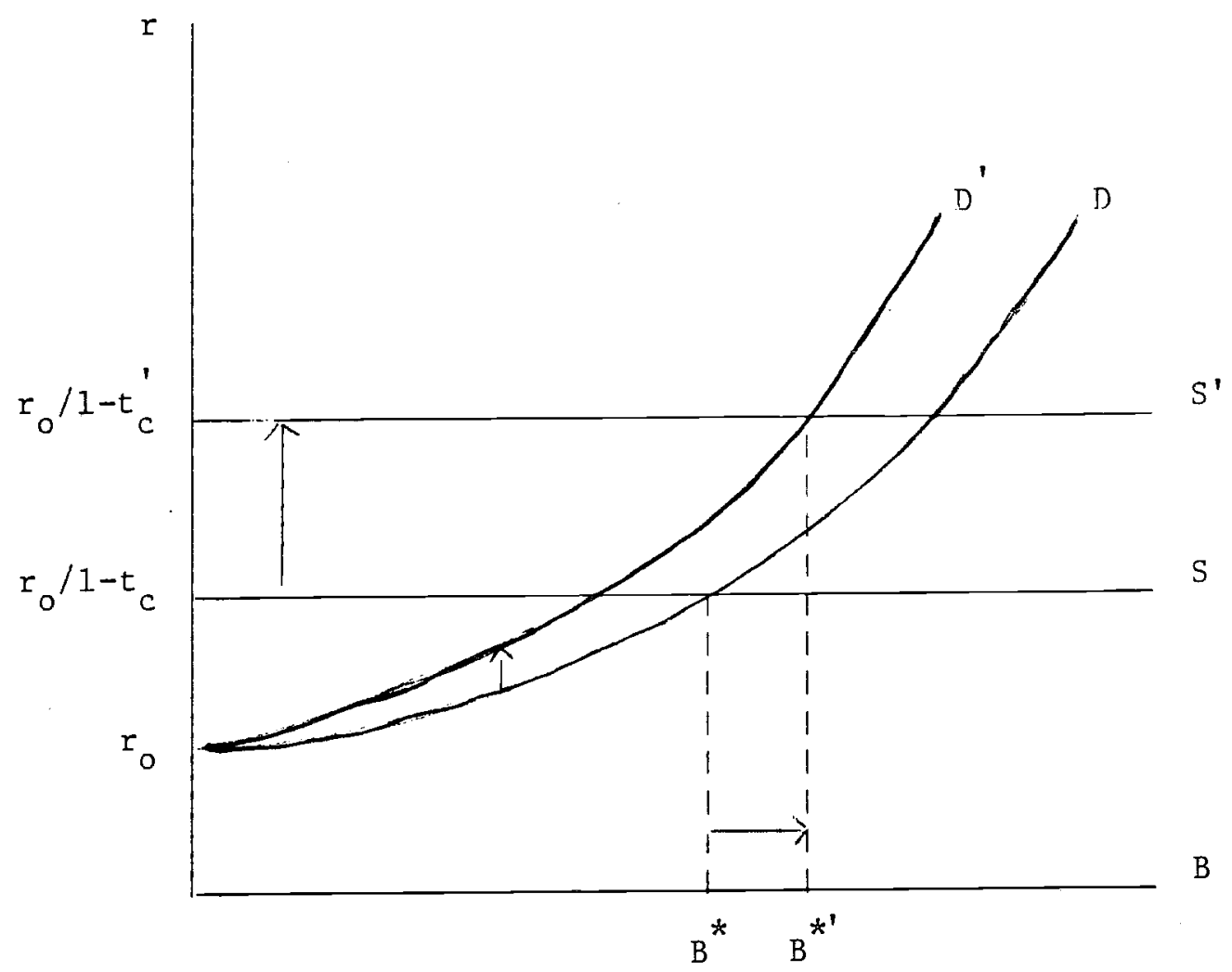

Figure 7

Change in Corporate Debt Caused By Simultaneous Increases in Corporate and Personal Tax Rates. 


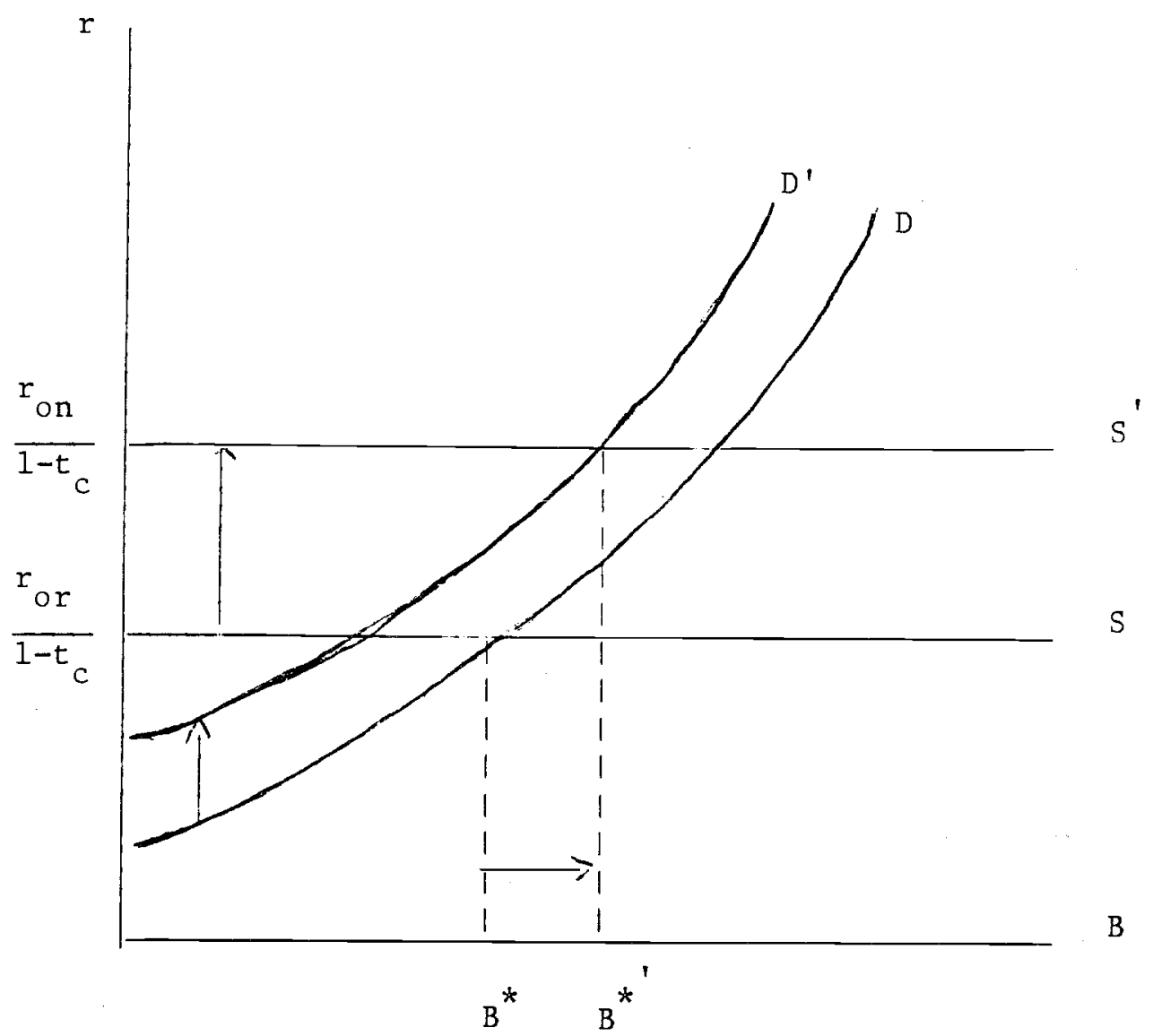

Figure 8

Change in Corporate Debt Caused By an Increase in Expected Inflation 


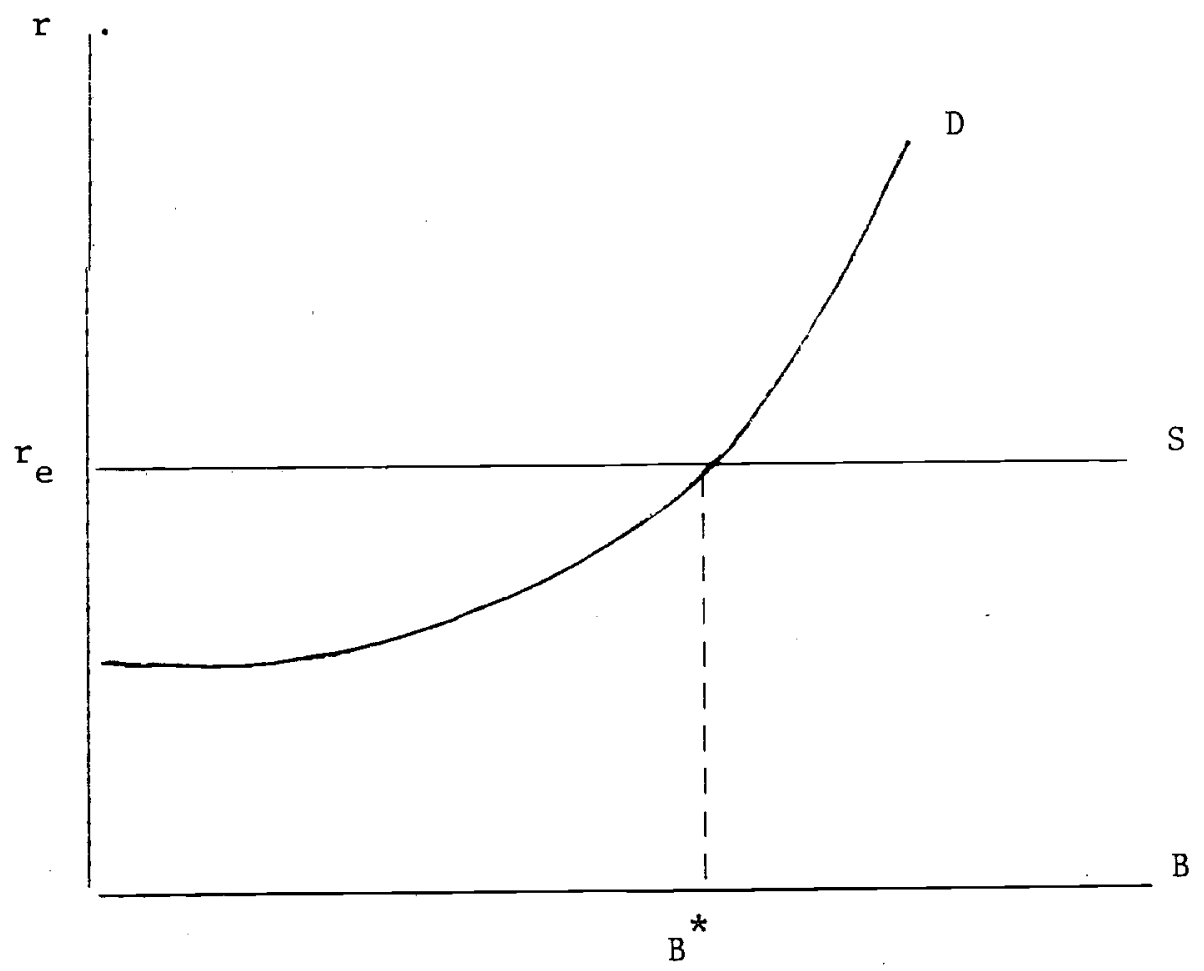

Figure 9

Equilibrium Amount of Corporate Debt When Return-Stream Transformation is Costless for Corporations But Not for Individuals 


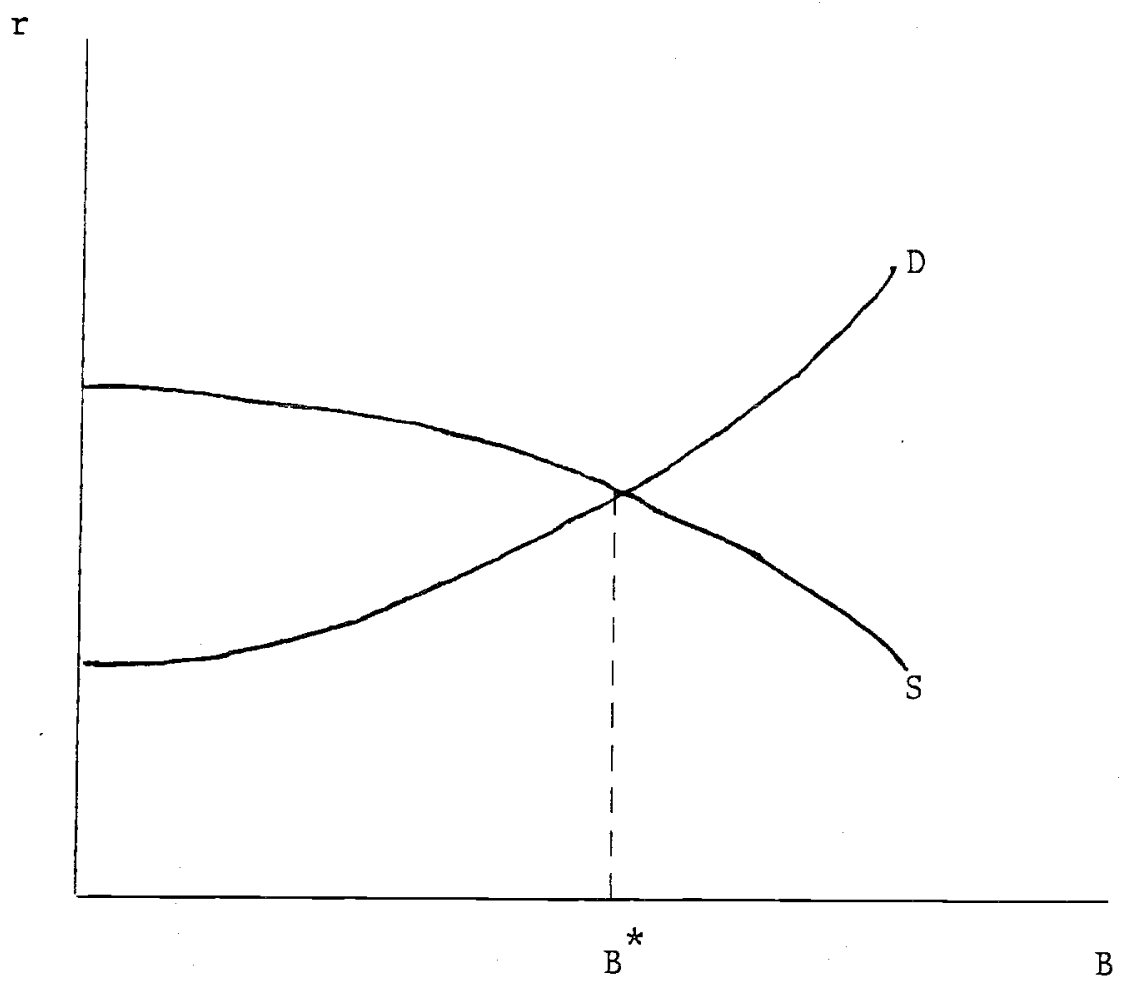

Figure 10

Supply and Demand for Corporate Debt: the General Case 
TABLE 1

Selected Book Value Balance Sheet Ratios, Al 1 U.S. Corporations and U.S. Manufacturing Corporation

All U.S. Corporations

$\overline{(1) \quad(2) \quad \text { (3) }}$

Yea
1926
1930

$L D / T C$

$.21 \quad .11$

$$
\begin{array}{r}
.21 \\
.22 \\
.23
\end{array}
$$$$
.23
$$$$
\begin{aligned}
& .23 \\
& .24
\end{aligned}
$$$$
.25
$$$$
\begin{array}{r}
.25 \\
.26
\end{array}
$$$$
.26
$$$$
\begin{aligned}
& .26 \\
& .26
\end{aligned}
$$$$
.26
$$$$
.26
$$$$
.26
$$$$
27
$$$$
.27
$$$$
.26
$$$$
.26
$$$$
.24
$$$$
.23
$$$$
.23
$$$$
.21
$$$$
.21
$$$$
.22
$$$$
.23
$$$$
.23
$$$$
.23
$$$$
.23
$$$$
.24
$$$$
.25
$$$$
.25
$$$$
.24
$$$$
.25
$$$$
.26
$$$$
.26
$$$$
.27
$$$$
.27
$$$$
.28
$$

.11

.11

$$
\begin{array}{r}
.09 \\
.09
\end{array}
$$$$
.10
$$$$
.11
$$$$
.11
$$$$
.10
$$$$
.11
$$$$
.10
$$$$
.10
$$$$
.10
$$$$
.09
$$$$
.08
$$$$
.08
$$$$
\begin{array}{r}
.08 \\
.08
\end{array}
$$$$
.08
$$$$
.08
$$

$$
\begin{aligned}
& .08 \\
& .07 \\
& .06 \\
& .06
\end{aligned}
$$$$
.07
$$$$
\begin{array}{r}
.06 \\
.05
\end{array}
$$$$
.05
$$$$
.05
$$$$
.04
$$$$
.04
$$$$
.04
$$$$
.04
$$$$
.04
$$$$
.03
$$$$
.03
$$$$
.03
$$$$
.03
$$$$
.53
$$$$
\begin{array}{r}
.53 \\
.54
\end{array}
$$$$
\begin{array}{r}
.54 \\
.55
\end{array}
$$$$
.57
$$$$
.58
$$$$
.61
$$$$
\begin{array}{r}
.63 \\
.64
\end{array}
$$$$
\begin{array}{r}
.04 \\
.65 \\
.64
\end{array}
$$$$
\begin{array}{r}
.63 \\
.62 \\
.62
\end{array}
$$$$
\begin{array}{r}
.62 \\
.63
\end{array}
$$$$
.63
$$$$
\begin{array}{r}
.63 \\
.65
\end{array}
$$$$
.65
$$$$
\begin{array}{r}
.65 \\
.66
\end{array}
$$$$
\begin{array}{r}
.66 \\
.65
\end{array}
$$$$
\begin{aligned}
& .65 \\
& .65 \\
& .65
\end{aligned}
$$$$
\begin{array}{r}
.65 \\
.66 \\
.66
\end{array}
$$$$
\begin{array}{r}
.66 \\
.66
\end{array}
$$$$
.09
$$$$
\mathrm{P} / \mathrm{TC}
$$$$
D / A
$$$$
.09 \quad .14
$$$$
.10 \quad .13
$$$$
.09 \quad .12
$$$$
.10 \quad .12
$$$$
.10 \quad .13
$$$$
.11 \quad .13
$$$$
.10 \quad .14
$$$$
.10 \quad .14
$$$$
.10 \quad .14
$$$$
.10 \quad .13
$$$$
.10 \quad .12
$$$$
11
$$$$
\begin{array}{ll}
.11 & .13 \\
.11 & .12
\end{array}
$$$$
.11 \quad .11
$$$$
\begin{array}{ll}
.11 & .11 \\
.10 & .10
\end{array}
$$$$
.10 \quad .10
$$$$
.090 .35
$$$$
\begin{array}{lll}
.09 & .09 & .36 \\
.09 & .34
\end{array}
$$$$
\begin{array}{lll}
.09 & .09 & .30
\end{array}
$$$$
\begin{array}{lll}
.09 & .09 & .30 \\
.10 & .09 & .30
\end{array}
$$$$
\begin{array}{lll}
.11 & .08 & .31
\end{array}
$$$$
\begin{array}{lll}
.11 & .08 & .31 \\
.12 & .07 & .31
\end{array}
$$$$
\begin{array}{lll}
.12 & .07 & .28
\end{array}
$$$$
\begin{array}{lll}
.11 & .06 & .31
\end{array}
$$$$
\begin{array}{lll}
.13 & .06 & .35
\end{array}
$$$$
\begin{array}{lll}
.135 & .06 & .35
\end{array}
$$$$
\begin{array}{lll}
.15 & .05 & .36 \\
.15 & .05 & .36
\end{array}
$$$$
\begin{array}{lll}
.15 & .05 & .34
\end{array}
$$$$
\begin{array}{lll}
.15 & .05 & .34 \\
.15 & .04 & .35
\end{array}
$$$$
\begin{array}{lll}
.16 & .04 & .36
\end{array}
$$$$
\begin{array}{ll}
.16 & .04 \\
.17 & .38
\end{array}
$$$$
\begin{array}{ll}
.17 & .38 \\
.17 & .37
\end{array}
$$$$
.17
$$$$
\begin{array}{lll}
.17 & & .38 \\
.17 & .03 & .38 \\
.18 & .03 & .43
\end{array}
$$$$
\cdot
$$$$
.03
$$$$
.38
$$$$
\begin{array}{lll}
.68 & .17 & .38 \\
.68 & .18 & .39 \\
.69 & .19 & .40
\end{array}
$$$$
.69 \quad .19 \quad .40
$$$$
\begin{array}{llll}
.69 & .21 & .02 & .43 \\
.69 & .21 & .42
\end{array}
$$$$
.69 \quad .21 \quad .42
$$$$
\begin{array}{lll}
.70 & .23 & .45 \\
.70 & .24 & .47
\end{array}
$$$$
\begin{array}{lll}
.70 & .24 & .47 \\
.71 & .26 & .49
\end{array}
$$$$
\begin{array}{lll}
.71 & .26 & .49 \\
.72 & .27 & .49
\end{array}
$$$$
\begin{array}{lll}
.72 & .27 & .49 \\
.72 & .26 & .49
\end{array}
$$$$
\begin{array}{ll}
.72 & .26 \\
.73 & .25
\end{array}
$$$$
.74 \quad .27
$$$$
.74
$$

Source: Internal Revenue Service, Statistics of Income

LD = Long-Term Bonds and Wies

$\mathrm{P}=$ Preferred St ock

$I C=$ Total Long-Term Capital = Long-Term Debt + Preferred Stock + Common Equity

$D=$ Total Debt

$A=$ Total Assets 
Table 2

Market Value Balance Sheet Ratios

(1) (2) (3) (4) (5) (6)

Holland \& Myers von Furstenberg Gordon \& Malkie1

\begin{tabular}{|c|c|c|c|c|c|c|}
\hline Year & $D /(D+P+E)$ & $D /(D+P+E)$ & $P /(D+P+E)$ & $D /(D+P+E)$ & $D /(D+P+E)$ & $P /(D+P+E)$ \\
\hline $\begin{array}{r}1926 \\
7\end{array}$ & & & & & .085 & .102 \\
\hline $\begin{array}{l}7 \\
8\end{array}$ & & & & & & \\
\hline $\begin{array}{l}8 \\
9\end{array}$ & .13 & & & & & \\
\hline 1930 & .18 & & & & .057 & .097 \\
\hline 1 & .25 & & & & & \\
\hline 2 & .39 & & & & & \\
\hline 3 & .37 & & & & & \\
\hline 4 & .32 & & & & & \\
\hline 5 & .36 & & & & .042 & .120 \\
\hline 6 & .24 & & & & & \\
\hline 7 & .27 & & & & & . \\
\hline 8 & .41 & & & & & \\
\hline 9 & .32 & & & & & \\
\hline 1940 & .33 & & & & & \\
\hline 1 & .38 & & & & .069 & .155 \\
\hline 2 & .44 & & & & & \\
\hline 3 & .28 & & & & & \\
\hline 4 & .28 & & & & & \\
\hline 5 & .25 & & & & & \\
\hline 6 & .16 & & & & & \\
\hline 7 & .17 & & & & .082 & .091 \\
\hline 8 & .17 & & & & & \\
\hline 9 & .23 & & & & & \\
\hline 1950 & .18 & & & & & \\
\hline 1 & .19 & & & & & \\
\hline 2 & .21 & .29 & .04 & & & \\
\hline 3 & .21 & .30 & .04 & & .133 & .058 \\
\hline 4 & .22 & .26 & .04 & & & \\
\hline 5 & .16 & .22 & .03 & & & \\
\hline 6 & .15 & .24 & .03 & & & \\
\hline 7 & .17 & .28 & .03 & .21 & & \\
\hline 8 & .17 & .25 & .03 & .17 & & \\
\hline 9 & .16 & .23 & .02 & .16 & .084 & .016 \\
\hline 1960 & .18 & .26 & .02 & .17 & & \\
\hline 1 & .16 & .23 & .02 & .16 & & \\
\hline 2 & .21 & .27 & .02 & .18 & & \\
\hline 3 & .18 & .24 & .02 & .17 & & \\
\hline 4 &. .17 & .22 & .02 & .16 & & \\
\hline 5 & .17 & .22 & .02 & .16 & .080 & .018 \\
\hline 6 & .22 & .28 & .02 & .19 & & \\
\hline 7 & .19 & .25 & .02 & .18 & & \\
\hline 8 & .18 & .23 & .02 & .18 & & \\
\hline 9 & .22 & .27 & .02 & .21 & & \\
\hline 1970 & .27 & .32 & .02 & .22 & & \\
\hline 1 & .26 & .32 & .02 & .23 & .132 & .017 \\
\hline 2 & .24 & .30 & .02 & .23 & & \\
\hline 3 & .31 & .35 & .02 & .28 & & \\
\hline 4 & .38 & .45 & .03 & .36 & & \\
\hline 5 & .32 & .40 & .03 & .32 & & \\
\hline 6 & .32 & .38 & .03 & .29 & 330 & 015 \\
\hline 7 & .32 & & & .32 & 230 & .012 \\
\hline 8 & .35 & & & .33 & & \\
\hline 9 & .38 & & & & & \\
\hline
\end{tabular}


Table 3

Balance Sheet Ratios with Debt and Preferred Stock Measured at Market Value, Assets at Replacement Cost

(1)

Goldsmith

Year

1900

1912

1922

1929

1933

1939

1945

6

7

8
9

1950

1

2

3

4

5

6

7

8

9

1960

1

1

3

4

5

6

7

8

9

1970

1

2

3

4

5

6

7

8

$\mathrm{D} / \mathrm{A}$

.32

.42

.28

.28

.35

.33

.13

.14

.14

.14

.13

.14

.15

.15

.15

.15

.16

.17

.17
(2)

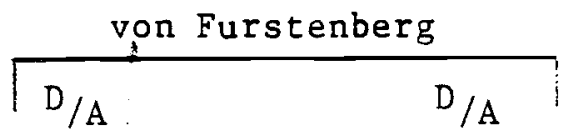

$(.15)^{1} .10$

.17

.02

.17

.18

.02

.03

.17

.03

.18

.03

.19

.02

.20

.02

.19

.02

.21

.02

.22

.02

.23

.02

.24

.02

.24

.02

.25

.02

.25

.02

.24

.02

.23

.23

.02

.23

.02

.02

.24

.02

.26

.02

.27

.02

.25

.02

.24

.02

.26

$.27^{2}$

.02

\section{Sources: Cited in text}

${ }^{1}$ Figure in parentheses is from Goldsmith (1956) Other figure is from Goldsmith (1963).

${ }^{2}$ Gordon and Malkiel (1981) update von Furstenberg's figures, using the same estimation method, through 1978. They do not report figures for preferred stock, however. 
Table 4

Flow of Funds Data: Proportions of Total Financing Accounted for by Particular Sources of Funds
(1)
(2)
(3)
(4)

(5)

Short-Term

Total Debt Long-Term Debt Liabilities Internal Funds

Period Total Sources $\frac{\text { Total Sources }}{\text { Total Sources }}$ Total Sources

New Stock

Total Sources

$\begin{array}{cc}1901-12 & .31 \\ 1913-22 & .29 \\ 1923-29 & .26 \\ 1930-39 & \text { negative } \\ 1940-45 & .15 \\ 1946-59 & .30 \\ 1960-69 & .36 \\ 1970-79 & .45\end{array}$

.23

.12

.22

negative

negative

.16

.18

.21

.08
.17
.04
egative
.20
.14
.18
.24

.24
.55

.60

.55

1.14

.80

.64

.62

.52
.14

.11

.19

.19

.05

.05

.02

.03 
Table 5

Corporate and Personal Tax Rates and Debt Incentive Tax Ratios
(1)
(2)
(3)
(4)

(5)

Lowest Value Highest Value

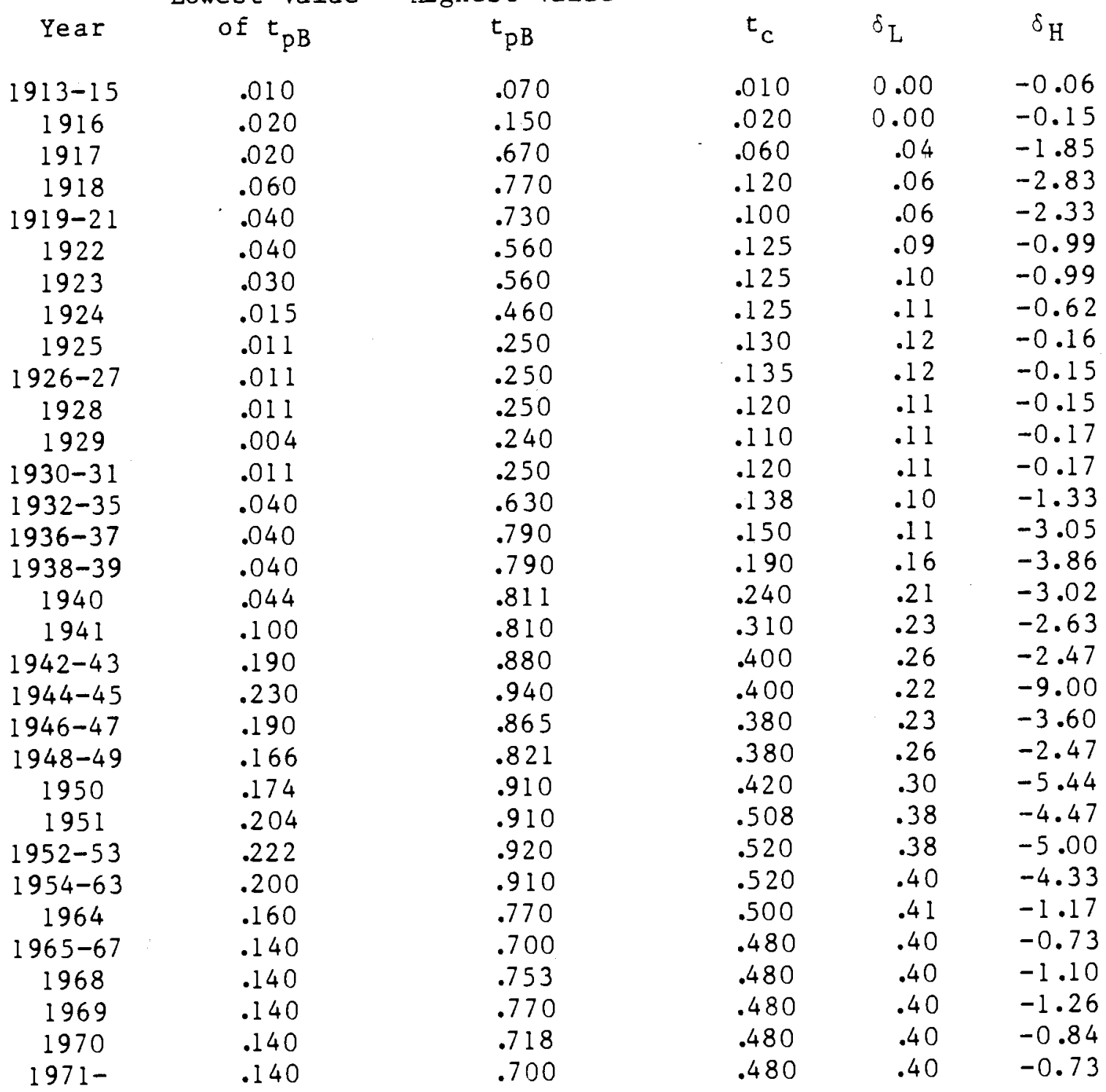


Table 6

Yearly Changes in Implicit GNP Price Deflator

\% Change in Deflator

1901

2

3

4

5

6

7

8

9

1910

1

2

3

4

5

6

7

8

1920

1
2
3
4
5
6
7
8

$-1.0$

4.1

$-0.7$

2.0

4.6

12.1

24.2

12.5

14.1

13.9

$-16.7$

$-8.1$

2.4

$-0.2$

1.4

$-1.5$

$-2.2$

1.6

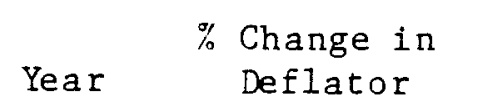

Year

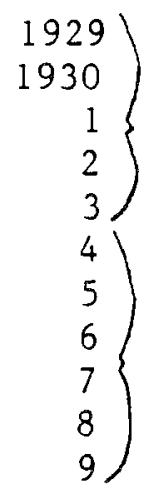

1940

Deflator

1957

$-2.1$

$\left.\begin{array}{l}1 \\ 2 \\ 3\end{array}\right\}$

4
5

6

9

1

2

3

4

5

6

7

8

9

1950

1

2

3

4

5

6
\% Change in
Deflator

3.4

1.7

2.4

1.6

0.9

1.8

1.5

1.5

2.2

3.2

3.0

4.4

5.1

5.4

5.0

4.2

5.7

8.7

9.3

5.2

5.8

7.3

8.5

9.0

Source: Historical Statistics of the United States and Economic Report of the President. 
Table 7

Ratios of Sectoral Liabilities outstanding to

Total Domestic Liabilities Outstanding

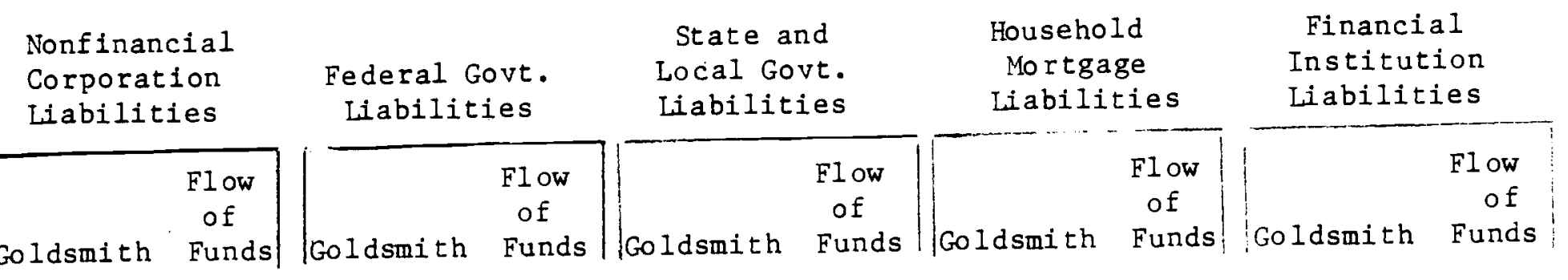
(1) (2)
(3)
(4)
(5) (6)
(7)
(8)

(9)

(10)

$900 \quad .34$

.01

.02

.06

.31

.36

.02

.01

.02

.30

.06

.03

.03

.04

.29

.06

.04

.32

.04

.33

.06

.35

.05

.35

.11

.11 .10

.38

.04

$.12 \quad .12$

.34

.02

.04

.03

.02

.02

.03

.02

.02

$.14 \quad .14$

$.32 \quad .31$

.03

.03

$.03 \quad .03$

.31

.03

.03

$.03 \quad .03$

.28

.29
.28

.26

$.15 \quad .15$

$.16 \quad .16$

.27

.03

.03

$.03 \quad .03$

$.04 \quad .04$

$.16 \quad .15$

$.26 \quad .23$

$.25 \quad .23$

$.24 \quad .22$

$.16 \quad .15$

.23

$.04 \quad .04$

$.04 \quad .04$

$.04 \quad .04$

$.04 \quad .04$

$.04 \quad .04$

.05

.05

.05

.05

.05

.05

.05

.05

.05

.04

.04

.05

.05

.05

.06

.06

.07

.07

.08

.44

.04

.42

.38

.05

.05

.06

.06

.07

.07

.08

.08

.09

.09

.10

.10

.11

.11

.11

$.43 \quad .38$

$.43 \quad .38$

$.43 \quad .38$

$.43 \quad .38$

$\begin{array}{ll}.42 & .37\end{array}$

$.43 \quad .37$

$.43 \quad .37$

$.43 \quad .37$

$.43 \quad .38$

$.42 \quad .37$

$\begin{array}{ll}.42 & .37\end{array}$

$.42 \quad .38$

$.42 \quad .38$

.38

.38

.12

.39

.14

.12

.39

.13

.12

.39

.12

.12

.40

.16

.11

.12

.40

.16

.11

.12

.40

.05

.12

.40

.17

.10

.10

.05

.12

.40

.17

.09

.05

.12

.40

.09

.12

.40

.17

.05

.12

.41

.17

.09

.05

.12

.42

.08

.04

.13

.41

.18

.08

.09

.04

.13

.41

.04

.13

.41

.17
.16

.04

.13

.09

.16

.04

.13

.41

.09

.13

.41

.41 
FOOTNOTES

1. Academic studies of aggregate corporate financing patterns include Kuznets (1961), Goldsmith (1958, 1963), Miller (1963), Sametz (1964), Friedman (1980) and Gordon and Malkiel (1981). Business journalists have also surveyed trends in corporate finance particularly in conjunction with the "capital shortage" discussions that were popular in the mid-1970's. See for example Business Week (1974).

2. Discussions that emphasize the postwar period fall primarily into the former category. Examples include Friedman (1980) and Gordon and Malkiel (1981). More popular discussions have also tended to emphasize deterioration in corporate balance sheets by pointing to increases in debt ratios. Business Week (1974) is a good example. Studies emphasizing stability in debt-equity proportions have tended to take a longer run view. These include Miller (1963) and Sametz (1964). Updated versions of these arguments also appear in Miller (1977) and Sametz and Keenan (1981).

3. An exception is Gordon and Malkiel (1981).

4. The literature on the topic is vast and no attempt will be made here to provide a complete list. Some of the more important contributions will be discussed in Section I below.

5. Miller's (1977) paper was perhaps the first to provide a theory explicitly aimed at the aggregate corporate capital structure.

6. Al though a government sector is not included in this stylized economy, it will be seen in subsequent sections that securities issued by the government may also have an important impact on the demand for corporate securities.

7. In keeping with most previous literature, corporate capital structure will be taken to represent the mix of debt and common equity financing. The framework employed is more general than that, however, and could also be used to include preferred stock and a variety of other hybrid financing instruments.

8. The financial institution sector is introduced in Stiglitz's (1974) generalization of MM. Even if financial transformation were costly for households on their own account, their demand for corporate debt would still be perfectly elastic if financial intermediaries could costlessly perform these services.

9. Examples of this theory may be found in Robichek and Myers (1966) and Kraus and Litzenberger (1973).

10. Implicitly, there are no personal taxes, or at least corporate debt and equity securities are subject to identical tax treatment at the personal level. 
11. The vertical intercept of the supply curve in Figure 4 thus cannot be identified precisely as it can be in Figure 3. Corporate tax considerations could of course be grafted onto the analysis, resulting in an upward shift of the supply curve. An example of work in this vein is Myers (1977), in which debt is subject to an agency cost but equity is not. In the absence of taxes, the supply curve for debt would slope downward starting from $r_{e}$ and in equilibrium no debt would be issued (in Myers' simple example, at least). When corporate taxes are introduced, however, the supply curve shifts upward and there is a positive equilibrium quantity of debt.

12. In the simplest version of Miller's model, equity is assumed to be free from personal taxation. Thus $r_{e}$, the certainty-equivalent return on equity, is the same as the certainty equivalent return, $r_{0}$, on tax-exempt bonds.

13. Suppose, for example, that initially $r_{0}=.05$ and $t_{c}=.5$. Corporations will be willing to freely substitute debt for equity financing at an interest rate $\mathrm{r}=.10$. At this rate the marginal bondholders will be those for whom $t_{p}=.5$. If $t_{c}$ then rises to .6 , corporations will be indifferent between debt and equity financing at $r=.125$. If the personal tax rate of those formerly in the $50 \%$ bracket also rises to .6, however, investors may wish to hold roughly the same amount of debt that they did before, but now with $\mathrm{r}=.125$. This ignores, however, any wealth effects on portfolio choice caused by the increase in personal tax rates. As ymmetric changes in personal tax rates may also yield extreme results. If all investors were suddenly pushed into tax brackets higher than $t_{c}$, for example, there would be no advantage to corporate debt for any investor and $B$ would fall to zero.

14. Note that at the initial equilibrium, $r=r_{r}$, and $r_{0}=r_{0 r}$.

15. The assertion that the demand curve makes a parallel upward shift is contingent upon personal tax rates remaining the same in the face of inflation.

16. Inflation would have the same effect in the tax savings - bankruptcy costs model of capital structure. Referring to Figure 3 , an increase in expected inflation would shift both the supply and demand curves upward, with the supply curve rising by more. This would result in an increase in ${ }^{\star}{ }^{\star}$. The Gordon - Malkiel (1981) model, which is essentially a tax savings - bankruptcy costs model, reaches this same conclusion about the effects of inflation.

17. See Hong (1977) and the references therein for a discussion of this hypothesis.

18. See Modigliani and Cohn (1979) for an elaboration of this point. A somewhat related point has been made by DeAngelo and Masulis (1980) who argue that inflation reduces the real value of tax shields such as depreciation, and thus induces firms to issue more debt in order to further shelter their real income. 
19. The Ross (1977) signalling model, not included among the theories reviewed, is another model of capital structure that does not rely on tax considerations. It is a kind of agency model, in that corporate capital structures are determined by a combination of information and managerial incentive problems. It is hard to see a definitive theory of the aggregate corporate capital structure emerging from the Ross model either, because, although firms would be continually trying to re-sort themselves in the eyes of investors, there seems to be no basis for linking this activity to changes in the aggregate mix of corporate securities.

20. The widely-used "complete" market model would be one in which these conditions are satisfied. Weaker conditions than market completeness (the "spanning" assumption, for example) would also be sufficient to generate perfectly elastic demands for securities if corporate financing choices were confined to traditional debt and equity securities.

21. A considerable literature exists, tracing this process of capital market development with particular emphasis on the role of financial institutions. See, for example, Davis and North (1971), Silber (1975) and James (1978).

22. A similar model of the firm valuation process is discussed in Senbet and Taggart (1981). It is shown there that the risk-adjustment factor,

$$
\operatorname{cov}\left(\tilde{u}_{2}^{i} \tilde{\Theta}\right) / E\left(\widetilde{U}_{1}^{i}\right) \text {, is negative for risk-averse individuals. }
$$

23. It will be assumed that this substitution is costless for firms.

24. Some qualification would be in order if corporate debt were subject to default risk or interest rate risk.

25. Barnea, Haugen and Senbet (1981) formulate a similar diagram to depict the equilibrium quantity of corporate debt. Their theory ultimately rests solely on tax considerations, however. In the absence of taxes, the agency costs associated with debt would dictate a zero-debt equilibrium in their model.

26. The total-debt-to-total-assets ratio was not examined by Miller.

27. After 1961 , the I.R.S. generally stopped reporting separate figures for preferred stock.

28. Some factors would tend in the opposite direction, however. The run-up in interest rates accompanying inflation would depress the market value of corporate debt and book values may thus tend to overstate the burden of this debt. In addition book value debt ratios may be understated by the omission of such "off-balance-sheet" financing sources as leases and unfunded pension liabilities. The use of these sources is believed to have grown tremendously in the 1960's and 1970's. One indication of the possible magnitude of this understatement is given in Gordon and Malkiel (1981). They calculate the ratio of debt to debt plus equity for the aggregate of firms included on the Compustat tape. Since 1973 the data on the tape include lease and pension liabilities. The ratios with and without these liabilities are as follows: 
Debt Ratio Without

Leases and Pensions
Debt Ratio Including

Leases and Pensions

$\begin{array}{lll}1973 & .367 & .497 \\ 1974 & .381 & .511 \\ 1975 & .374 & .499 \\ 1976 & .362 & .485 \\ 1977 & .358 & .473 \\ 1978 & .358 & .462\end{array}$

29. See Modigliani and Cohn (1979) for an argument that the market does not properly adjust for inflation in determining equity values. By their argument, market value debt ratios would be substantially overstated.

30. Myers (1977), for example, has argued that a firm's capacity to issue debt is closely related to its assets-in-place. The total market value of assets, on, the other hand, reflects not only assets-in-place but also future investment opportunities and Myers points out that firms may not find it advantageous to borrow against these opportunities. Thus the replacement value of assets, which reflects only assets-in-place, may be a better measure of debt capacity.

31. One problem is that von Furstenberg's measure of debt is different from Gold smith's. In von Furstenberg, non-interest bearing liabilities have been netted out against the asset side of the balance sheet, while interest-bearing financial assets have been netted out against the liability side in computing this ratio. To make the figures as closely comparable as possible, the same procedure has been used in calculating debt ratios from Goldsmith's data. Nevertheless, the detail in Goldsmith's data is not the same as that in the Flow-of-Funds accounts, from which von Furstenberg worked, and thus ratios would not be expected to be identical.

32. To the extent that some investment expenditures, such as research and development, are expensed immediately, however, the extent of equity financing may still be understated somewhat. There are also other problems inherent in flow-of-funds data. Von Furstenberg and Malkiel (1977) argue that these data are misleading in inflationary times because they fail to recognize the reduction in the real value of previously outstanding debt caused by inflation. In addition the Flow-of Funds Accounts published by the Federal Reserve System lump preferred stock financing together with common equity financing.

33. In general, as discussed in Miller (1977), the expression should be $\delta=1-\left(1-t_{c}\right)\left(1-t_{p s}\right) /\left(1-t_{p B}\right)$, where $t_{p s}$ is the personal tax rate applicable to income from corporale stock. This latter rate should be some mixture of the ordinary income tax rate (for dividend income) and the capital gains rate. In keeping with Miller, $t_{p s}$ is ignored here, on the argument that deferral of capital gains will make the effective tax rate on stock income quite smal1. To the extent that $t_{p s}$ is positive, however, it will increase somewhat corporations' incentive to substitute debt for equity. 
34. See Kim, Lewellen and McConnel1 (1980) and Taggart (1980) for discussions of how investors in different tax brackets sort themselves into clienteles with respect to their preferences for corporate leverage. At Miller's equilibrium, the marginal investor will have $t_{p B}=t_{c}$ and $\delta=0$. Furthermore, this investor will be just indifferent between holding taxable and tax-exempt bonds, so for him $r\left(1-t_{p_{B}}\right)=r_{0}$. In equilibrium, then, $\delta=1-\left(1-t_{c}\right) /\left(1-t_{p B}\right)=-\operatorname{rr}\left(1-t_{c}\right) / r\left(1-t_{p B}\right)$

$$
=1-r\left(1-t_{c}\right) / r_{0} \stackrel{c}{=} 0 \text { and } t h u s \text { (20) is consistent with }(1) \text {. }
$$

35. The presence of tax-exempt investors might also add to the demand for corporate leverage. Restrictions on the riskiness of individual securities in their portfolios, however, might limit the ability of taxexempt institutions to purchase stock in highly-levered corporations.

36. The upward trend in corporate tax rates is also broadly consistent with the secular decline in preferred stock financing.

37. In principle, expected rates of inflation would be preferred. Over long periods, one might expect at least a rough correspondence between expected and realized inflation rates.

38. This increase in debt financing is particularly apparent if one examines yearly Flow of Funds data. In 1946 and 1947, for example, the years of greatest inflation around that period, total debt accounted for $52 \%$ and $49 \%$, respectively, of total sources of funds for the corporate sector. In large part this increased debt financing was accounted for by heavy reliance on short term liabilities, which made up $33 \%$ and $29 \%$, respectively, of total sources.

39. The supply of government debt might reasonably be viewed as exogenous to the system. Observed amounts of household mortgages, on the other hand, will presumably be more affected by prevailing capital market yields.

40. The decline is much more dramatic in Goldsmith's data than in the Flow of Funds data.

41. To the extent that tax considerations and inflation have affected corporate liabilities and household mortgages in the same direction, this may not be surprising.

42. Recent work by Friedman (1981) bears a relationship to this idea. Friedman observes that the ratio of total debt to GNP has been remarkably stable for the U.S. economy, even though the ratio of any one sector's liabilities to GNP may have shown considerable trends. There appears to be some sort of substitution relationship, then, between the liabilities of the economy's various sectors.

43. One cannot look to federal government securities on this score, however. The maturity structure of both federal government and corporate debt has generally been shortened over the postwar period, so it is difficult to make any broad argument that issues of long-term government debt have pushed corporations to the short end of the market. Since 1975, though, it is true that the average maturity of government debt has lengthened considerably. See Friedman (1980). 
44. In the immediate post-Depression years, of course, investors may have become increasingly skeptical about the safety of corporate debt.

45. Ultimately, this involves a shift in the bearing of interest rate risk from shareholders and other owners of financial institutions and from liability insurance agencies to the shareholders of nonfinancial corporations. A more complete explanation would detail the mechanism by which such a shift might take place. In particular, the stance of financial institution regulators might be an important factor.

46. See Greenbaum and Haywood (1971) for a discussion of the role of technology and regulation in the intermediation possibilities open to financial institutions. 


\section{REFERENCES}

A. Barnea, R. A. Haugen and L. W. Senbet, "An Equilibrium Analysis of Debt Financing Under Costly Tax Arbitrage and Agency Problems," Journal of Finance 36 (June 1981), 569-81.

Business Week, "The Debt Economy", special issue, October 12, 1974.

J. C. Ciccolo, Jr., "Changing Balance Sheet Relationships in the U.S. Manufacturing Sector", NBER Working Paper No. 702, June 1981.

L. E. Davis and D. C. North, Institutional Change and American Economic Growth (Cambridge: Cambridge University Press, 1971).

H. DeAngelo and R. W. Masulis, "Optimal Capital Structure Under Corporate and Personal Taxation", Journal of Financial Economics 8 (March 1980), 3-29.

Friedman, B. M., "Postwar Changes in the American Financial Markets" in M. Feldstein, ed., The American Economy in Transition (Chicago: University of Chicago Press, 1980).

, "Debt and Economic Activity in the United States", NBER Working Paper No. 704, June 1981 .

R. W. Goldsmith A Study of Saving in the United States. 3 vols. (Princeton: Princeton University Press, 1956).

Financial Intermediaries in the American Economy Since 1900 (Princeton: Princeton University Press, 1958).

, R. E. Lipsey and M. Mendelson, Studies in the National Balance Sheet of the United States. 2 vols. (Princeton: Princeton University Press, 1963).

R. H. Gordon and B. G. Malkiel, "Taxation and Corporate Finance", in H. J. Aaron and J. A. Pechman, eds. How Taxes Affect Economic Behavior (Washington, D.C.: The Brookings Institution, 1981).

S. I. Greenbaum and C.F. Haywood, "Secular Change in the Financial Services Industry", Journal of Money, Credit and Banking 3 (May 1971), 57 1-89.

P. Grier and P. Strebe1, "The Empirical Relationship Between Taxation and Capital Structure," Financial Review 15 (Fall 1980), 45-57.

D. M. Holland and S. C. Myers, "Trends in Corporate Profitability and Capital Costs" in R. Lindsay, ed. The Nation's Capital Needs: Three Studies (New York: Committee for Economic Development, 1979).

H. Hong, "Inflation and the Market Value of the Firm: Theory and Tests", Journal of Finance 32 (September 1977), 1031-48.

J. A. James, Money and Capital Markets in Postbellum America (Princeton: Princeton University Press, 1978). 
M. C. Jensen and W. H. Meckling, "Theory of the Firm: Managerial Behavior, Agency, Costs and Ownership Structure", Journal of Financial Economics 3 (October 1976), pp. 305-60.

E. H. Kim, W. G. Lewellen and J. J. McConnell, "Financial Leverage Clienteles: Theory and Evidence" Journal of Financial Economics 7 (March 1979), 83-109.

A. Kraus and R. Litzenberger, "A State-Preference Model of Optimal Financial Leverage," Journal of Finance 28 (September 1973), 911-23.

S. Kuznets, Capital in the American Economy. Its Formation and Financing (Princeton: Princeton University Press, 1961).

M. H. Miller, "The Corporation Income Tax and Corporate Financial Policies" in Commission on Money and Credit, Stabilization Policies (Englewood Cliffs, N.J.: Prentice Hall, 1963). , "Debt and Taxes", Journal of Finance 32 (May 1977), 261-75.

F. Modigliani and R. A. Cohn, "Inflation, Rational Valuation and the Market" Financial Analysts Journal (March/April 1979), 24-44.

F. Modigliani and M. H. Miller, "The Cost of Capital, Corporation Finance and the Theory of Investment" American Economic Review 48 (June 1958), 261-97.

\section{"Corporate Income Taxes and the Cost of Capital - A}

Correction" American Economic Review 53 (June 1963), 433-43.

S. C. Myers, "Determinants of Corporate Borrowing", Journal of Financial Economics 5 (November 1977), 147-75.

J. A. Pechman, Federal Tax Policy, 3rd Ed. (Washington, D.C.: Brookings Institution, 1977).

A. A. Robichek and S. C. Myers, "Problems in the Theory of Optimal Capital Structure," Journal of Financial and Quantitative Analysis 1 (June 1966), $1-35$.

S. A. Ross, "The Determination of Financial Structure: The Incentive Signalling Approach", Bell Journal of Economics 8 (Spring 1977), 23-40.

A. W. Sametz, "Trends in the Volume and Composition of Equity Finance", Journal of Finance 19 (September 1964), 450-69.

, and W. M. Keenan, "Business Investment Demand" in M.E. Polakoff, T.A. Durkin et. a1., Financial Institutions and Markets, 2nd Ed. (Boston: Houghton Mifflin, $198 \overline{1 .}$

L. W. Senbet and R. A. Taggart, Jr., "Capital St ructure Equilibrium Under Incomplete Market Conditions", NBER Working Paper No. 747, September 1981.

W. B. Silber, ed. Financial Innovation (Lexington Mass.: D.C. Heath, 1975). 
J Stiglitz, "On the Irrelevance of Corporate Financial Policy" American Economic Review 64 (December 1974), 851-66.

R. A. Taggart, Jr. "Taxes and Corporate Capital Structure in an Incomplete Market, Journal of Finance 35 (June 1980), 645-59.

G. M. von Furstenberg, "Corporate Investment: Does Market Valuation Matter in the Aggregate?", Brookings Papers on Economic Activity (2, 1977), 347-97.

, and B. G. Malkiel, "Financial Analysis in an Inflationary Environment" Journal of Finance 32 (May 1977), 575-88. 